presicential addresses ever heard at a meeting of the Association, and members would thank Dr. Nathan Raw most cordially for it.

The resolution was put to the meeting by the proposer, Dr. Worth, and carried by acclamation.

The President said he wished to thank the proposer and seconder, and all present, for their kindness in listening to his address and for the appreciation accorded him. It was very difficult to select a suitable subject for an address of this kind: and if one confined oneself to the purely medical or scientific side of the specialty it might prove exceedingly dull. Perhaps the case was best met by a subject in which there was a little of both, and he was very glad it appeared to have met with approval.

[Adjournment.]

\title{
THE ANNUAL DINNER.
}

The Annual Dinner took place on Wednesday, July ro, at the Hotel Metropole, Northumberland Avenue. The President, Dr. Nathan Raw, occupied the chair.

The official guests included : His Worship The Mayor of Westminster (Major

Vivian B. Rogers, D.S.O.), Sir Arthur Robinson, G.C.B., C.B.E. (Permanent Secretary, Ministry of Health), Sir Charles Pinkham, O.B.E., J.P. (Chairman, Middlesex County Council), L. G. Brock, Esq., C.B. (Chairman, Board of Control), Mrs. Pinsent (Commissioner, Board of Control), Sir George Buchanan, C.B. (Ministry of Health), The Right Hon. Lord Riddell (Chairman, Royal Free Hospital), Dr. J. H. Pameijer (Dutch Delegate), Dr. Henri Flournoy (Swiss Delegate), Sir J. Rose Bradford, M.D. (President, Royal College of Physicians), Lady Barrett, D.B.E., M.D. (Dean, London [Royal Free Hospital] School of Medicine, Sir James Purves Stewart, K.C.M.G., C.B., M.D. (Senior Physician, Westminster Hospital), Dr. Woodward (Dean of Westminster Hospital), Dr. N. C. Horner (Editor, British Medical Journal), Dr. Alfred Cox, O.B.E. (Medical Secretary of the British Medical Association), Miss Vickers (Secretary, Mental After-Care Association).

The following, among others, were invited, but were unable to be present : The Lord Chancellor, The Rt. Hon. Arthur Greenwood, M.P. (Minister of Health), His Eminence Cardinal Bourne, The Lord Chief Justice of England, The Dean of Westminster, Lord Southborough, G.C.B., G.C.M.G., The Earl of Birkenhead, Surgeon Vice-Admiral Gaskell, C.B., Lt.-General Sir Matthew H. G. Fell, K.C.B., The Vice-Chancellor of the University of London, The President, Royal College of Surgeons, The President, Medical Society of London, Sir Claud Schuster, The President, Royal Society of Medicine, Sir Robert Bolam (Chairman, Council, British Medical Association), Miss Musson (Chairman, G.N.C. for Eng. and Wales), Lt--Col. F. E. Fremantle, M.P., M.D., The Hon. H. C. Bailey (Board of Control), Sir Wm. G. Lobjoit, (Middlesex C.C.), Mr. Hubert J. Greenwood, D.L. (Chairman, Horton Mental Hospital), Mr. de Salis (Middlesex C.C.), Dr. Costley White (Headmaster, Westminster School), Professor Winifred Cullis, C.B.E., Sir Philip Gibbs, Sir George Newman, K.C.B., M.D. (Ministry of Health), Mr. K. A. Wolfe Barry, Mr. William Turner, F.R.C.S. (Westminster Hospital), Mr. Arthur Evans, F.R.C.S. (Westminister Hospital), Sir James Berry, M.D., The Hon. Mr Justice McCardie, Sir Squire Sprigge (Editor, Lancet), Mr. Parker Morris (Town Clerk, City of Westminster), Sir Montague Cox (Clerk, London County Council), Mr. R. H. Curtis (Chief Officer, London County Mental Hospitals).

TOASTS.

The PResident proposed the toast of "The King," and it was loyally pledged.

"The City of Westminster."

Lt.-Col. J. R. LORD, C.B.E., in proposing this toast, said that at the meeting of the Association that afternoon the President had given a moving and instructive description of Fear. The President had not, however, revealed to them what was to be understood by " funk," but one could regard it as yielding to fear and decamping. That was just what he felt like doing that moment. His great fear was that he would prove a totally inadequate substitute for Sir James CrichtonBrowne, to whom rightly belonged the honour of proposing that toast. Sir James, who was one of the most eloquent men of our times, and whose absence all would 
deplore, would no doubt have told them in stately phrases that Westminster, first known as "Thorney Island," or as " Apple Island," was a busy place long before London came into existence. He would have said of it that the date of its first Charter was lost in antiquity, and that it was the pulsating heart, not of England, but of the Fmpire.

But for him, the speaker, to speak adequately of the part Westminster had played in history was impossible. He might, however, venture to portray the thoughts of the many pilgrims who wandered with respect, even reverence, through its highways, both broad and narrow. Who of them, the speaker asked, could fail to note that set in its mighty buildings, some of brick, some of stone, some mightier still of steel and concrete, was the Constitution of the British Empire, who could fail to feel when under the spell of Westminster's ancient abbey church that enshrined in it were the triumphs and tragedies of the history of England ? And lastly, who of them could possibly think of any other place on earth as the proper site for the Imperial Cenotaph. (Applause.)

"Mr. Mayor," he continued, " you preside over an imperial city, a city of palaces, unique in its history and traditions. In this respect you occupy a proud position among mayors. You no doubt are proud of Westminster, but it is no less true that Westminster is proud of you. It is well known that you have earned the high respect and goodwill of its citizens by your devotion to civic work. This is enhanced by your fine record as a soldier during the war. Such a record was to be expected, for where is the Marlborough boy who is without patriotism-love for home and country-both in peace and war. Has not that great school supplied more Empire-builders and soldiers than any other in this country ?"

He, the speaker, was to-night the mouthpiece of those present, all of whom desired to do honour to Westminster, the seat of Imperial government, the home of Majesty, and to its Mayor for his fine work as citizen and soldier, and on behalf of the Association to thank him for his hearty welcome and kind hospitality.

Before, however, the toast was honoured, he would like to touch on two other matters. Westminster was the home of Olympius, so had said Ian Hay, but an Olympius surely now dethroned. Was not the going to sleep and falling down of one of the Horse Guards horses that awaited to carry far and wide the news that England had let loose the reins of war, a symbol of this ? (Loud laughter.) Was not Scotland Yard in Westminster, and the chief of the Metropolitan Police one of its citizens? That reminded him, the speaker, that in the Westminster of the eighteenth century thieves used to cut out the backs of carriages and steal the wigs of gentlemen and the decorative headgear of the ladies. The Overseers of those days ordered people to sit on the front seat of carriages and face the rear, to prevent those robberies. (Laughter.) The other matter he would like to refer to briefly as something remarkable that Westminster was proud of was its past Overseers' Society, founded in I 7 r3. It held an annual dinner, and the speaker had been privileged more than once to be a guest at that dinner. On one of those occasions, not the last, be it noted, he had to speak for the Army, and at short notice, a field-marshal who was present having rebelled-surely a privilege limited to that rank. (Laughter.) The Mayor had inherited the duties of this most remarkable set of men, the Overseers of Westminster, but not the tobacco box, now so encased as to be a small mountain, which was given to the Overseers in I7I 3 by a barber-surgeon named Henry Monck. Col. Lord then bade the company present rise and drink to the health of Westminster and its mayor. (Loud applause.)

His Worship the Mayor of Westminster (Major Vivian Rogers, D.S.O., M.C., J.P.), in responding to the toast, said he felt that it was an undue honour to be privileged to address this Association twice in one day. Col. Lord had spoken eloquently and kindly of the City over which he, the speaker, had the honour to preside, and had referred to many points of interest it presented. He, the speaker, would like to describe one or two more, if in so doing he would not be boring them. Dr. Lord first spoke of the antiquity of Westminster's Charter. The Charter was not really ancient, but Westminster was. The first record the City possessed of boundaries was in the year 785 , when Offa, king of the Mercians, laid down certain boundaries, which were subsequently confirmed by King Edgar in 951. An interesting point was that the boundaries of that remote time included a certain portion of what was now the City of London. He had had an interesting experience the other night. He was at a function with an American general who was very interested in Westminster. His daughter, he said, could not understand what 
the "City of Westminster" meant when she saw it on the houses of every street corner. Therefore he, the speaker, explained what he need not explain to the present company, namely, the municipal government of London, amplifying his remarks by saying that their first dated boundary went back to 785 A.D. She said " 1785 ?" and he replied, "No, 785 ," at which she exclaimed, "What? 700 years before my country was discovered?" That gave an idea of its antiquity. It was not a City then; it became one when a Bishop was appointed to it in 1540. But the bishopric lasted only nine years, as it was abolished in 1559. Still, by courtesy, Westminster remained a City until, by Royal Charter, in 190o, Queen Victoria confirmed the title of "City."

Westminster was a city over which anyone, as Col. Lord had said, might be proud to have the honour of presiding. He was particularly proud of it. He had worked for the past twenty-five years in Westminster, and he knew most of its corners. It was not easy to know the whole of it. It covered four square miles, and there were roo miles of streets to look after. The number of public buildings and places of interest within the boundaries of Westminster was almost without limit. When one thought of the Royal Palaces, the Houses of Parliament, the Abbey, the Government buildings, the Law Courts - to say nothing of the principal theatres, and he thought it would be agreed that London's chief shopping centres were within its precincts-that remark was borne out. Apart from that, Westminster had the distinction of being the richest city in England, its rateable value at the moment being little short of ten millions, and he rather anticipated that when the quinquennial valuation occurred next year it would exceed the ten-million mark.

He did not propose to weary the company with lengthy remarks. Apparently something boring was expected from him, as he noticed that a musical interlude had been arranged to follow his speech-(Laughter)-a privilege which had been accorded to no other speaker. He wished to thank all the members of the Royal Medico-Psychological Association for the very kind welcome extended to him in his position as Mayor of Westminster City, and he wished every member of this gathering the best of luck and success during the remainder of their Annual Conference, and for ever after. (Applause.)

“The University of London, Westminster Hospital School of Medicine."

Prof. J. Shaw Bolton said it was with the greatest possible pleasure that he rose to propose this toast. The toast was a double-barrelled one, the first doublebarrelled toast he had ever proposed, so he would find it difficult to steer a course between doing justice to himself and boring his hearers. He would endeavour at all events to avoid boring the assembled company. He had the honour of being a member of the University of Leeds, but he would disappoint those who expected him to speak of that University; he felt he must propose the toast as a graduate of the University of London. In the course of his remarks he would like to say what the University had done for general education. The idea of university education a century ago was attending a seat of learning where men went through a training before they went home to work as they chose. They occupied the greater part of their time enjoying the mental and physical skill of the few residents rather than showing any tendency to study seriously for their future careers. The University of London did not go in for that. Its system of examination, introduced in to this country for the first time there, could be described as an intellectual apprenticeship. Thousands of young men and boys-himself among the numberwere able in the first three-quarters of a century of its existence, to obtain a degree based upon knowledge, without having seen the inside of either a university or a They acquired their information somehow, and that it was acquired was proved by the test of examination. He did not mind telling the company how he came to the University. He was assisted to matriculate by a reverend gentleman who produced in him an undying hatred of Latin and French. He worked for the Intermediate by himself, in a wooden shed, and he employed cats and pigeons, because they were cheaper and easier to obtain than were rabbits and fowls. As soon as he passed the Intermediate examination he had to give up the study of science, as he was unable to obtain facilities for carrying on. Therefore he had to take up mental and moral science. He could not say how much he hated these subjects, particularly moral science, and he would not have believed at that time that forty years afterwards he would be in a position such as he now occupied. He was 
one of many thousands who obtained a degree in that way. He did not wish to propose this course to anyone; he was merely indicating how it came about.

He would now say, in a word or two, what was absolutely true with regard to the University of London. In London it had been possible to obtain a University degree, also to obtain the qualification of the Colleges of Physicians and Surgeons. For more than half a century it had been a serious source of discomfort to diplomates in London that they did not have a University residence. But he could say, with truth, that the graduates of London were as well, if not better, trained than in any of the provincial Universities. During the past quarter of a century the University of London had extended its spheres of influence by undertaking the teaching as well as the examining of candidates. It had incorporated a number of the largest and most important Colleges. The only thing the University of London missed-and it missed it greatly - was a suitable home for a body of its outstanding importance. That would come in the future, but at the present time, and ever since it was founded, the University of London existed in the lives of its undergraduates.

He now proceeded to the second half of the toast, that of the Westminster Hospital School of Medicine. He knew but little personally about that School, but he knew that if the School was represented by other teachers of the outstanding importance of Sir James Purves Stewart, it must necessarily be a very great teaching School. He believed that the Westminster was one of the oldest hospitals in London. It differed from many in the fact that it had been rebuilt four or five times. It had recently associated itself with a mental hospital, and he would like to spend a few minutes in referring to the importance of this. In the case of Leeds, Wakefield Mental Hospital was closely associated with the University, and he occupied a position on the staff of that University. That arrangement, however, did not hold to the same extent in many parts of the country. Another example was Springfield Mental Hospital, the Medical Superintendent of which was the General Secretary of this Association. Such an association between mental hospital and university was extremely important. The case of Westminster differed from the association in the north, because the consultants of Westminster Hospital undertook to obtain their advice from Springfield Mental Hospital, and the latter undertook to provide a lecturer, and also to provide a place in the curriculum of the University of London. There was also at the same time an important social association. The sports ground of Springfield Mental Hospital was used by the students of Westminster Hospital, and there was an association between the two in projecting games, etc. It foreshadowed, he thought, the time when a similar connection would be general throughout the country. He had the greatest pleasure in proposing the toast, coupled with the name of Sir James Purves Stewart. (Applause.)

Sir James Purves Stewart, K.C.M.G., C.B., in responding to the toast, said that the latter part of Prof. Shaw Bolton's speech was what he would have said himself. He found himself in the position of a fellow countryman of his own, who had a horse suffering from an asthmatic affection. He met a veterinary friend in the street and asked his advice as to what he should do. The reply was to indicate a certain cure. He told him to procure a certain powder, put it in a long glass tube, insert the tube in the horse's mouth, then blow the powder in. Next day the veterinary surgeon met the man and asked him if he had carried out the advice. He said yes, he did just as he was told, but the horse blew first! (Laughter.) Prof. Shaw Bolton had " blown first," because he had told the company all those things about Westminster Hospital which he had hoped would have been reserved for him, the speaker, though admittedly he had done it better than he, Sir James, would have done. It was therefore necessary that the speaker should approach the matter from a different angle.

To one who, like himself, was not a medico-psychologist, there was bound to be some hesitation in addressing a medico-psychological audience such as this. And this hesitation in his case amounted almost to a phobia, but his own fear was due to a different cause from Col. Lord's. The speaker's phobia was due to the possibility that an innocent outsider like himself was facing a number of psycho-analysts -Freudian or otherwise-concealed behind innocent-looking cigars. These analysts often attached most remarkable meanings to most innocent gestures. The safest thing would appear to be to address these distinguished psycho-analysts from behind a curtain. But he assured members of the Association that the 
dominant complex of the guests to-night lay close to the surface, and that it was one of sincere gratitude for the kindly hospitality.

\section{"Allied Societies."}

Sir HUBert Bond, K.B.E., said the terms in which this toast was listed entrusted its proposer with a somewhat roving commission. Its ambit was not confined to London's seventy medical societies, nor even to England and Wales, where, besides five in the Principality, there were 98 provincial medical societies, at least eight of which published transactions or a journal, and of which the first was said to have been founded at Warrington about 1774. Since their own Association drew its members from all parts of the Empire and was peripatetic throughout Great Britain and Ireland, the company would wish him to include in their thoughts the 25 Scottish and 5 Irish medical societies, as well as the many others that flourished throughout the Empire; and to extend to them, severally and collectively, fraternal greetings, together with most hearty good wishes for their combined prosperity, and for their success in their great aim which underlay every medical society-namely, the benefit of humanity, especially in the maintenance of health.

Even then they would find the horizon receding; because science was heedless of frontiers, and they would be ill-content to sit down until they had extended not less cordial wishes to the many similar societies which enriched the life of nations without the British Empire, not a few of whom were represented in the Association's roll of Honorary and Corresponding Members, some of whose delegates had honoured the Association by their presence at that annual meeting, and at that evening's gathering.

Again, were there not, besides dental societies, also a growing number of nurses' professional associations? They were certainly allies. Yet again, there were various cognate societies which, being partly lay as well as medical, served to preserve a just balance between professional enthusiasm and that wiich was acceptable to the public.

So were he to interpret his commission in its wide sense, and to attempt to do justice to the position of all these societies, whose work one was so often glad to fall back upon in aid of one's efforts, it was patent for how tediously long the patience of the company would be tried. Their just alarm at the bare thought of such an infliction, however, would be quickly dispelled, as five minutes' attention was all he asked. And in further justification for short-circuiting much that indeed ought to find a place in any attempted recognition of the fine work done by the allied societies was the fact that scarcely a fortnight ago there appeared, in the British Medical Journal, a lecture-delivered before the London Clinical Societyby Sir Humphry Rolleston upon "Medical Friendships, Clubs and Societies," in which, with great charm, he told many highly interesting facts concerning the rise and progress of these societies.

It was, he said, the reply to this toast, rather than its proposer, which the gathering desired to hear; but the speaker's consequent desire to be brief would scarcely excuse his sitting down without short allusion to some of those societies. It would be of interest to know when and where a body of persons practising medicine, either mystic or scientific, first banded themselves together into an association or society-probably in the far distant days of an early Egyptian civilization. If the answer to such a question had to remain shrouded in doubt, there appeared to be no dubiety, according to accounts given in this and last week's newspapersThe Observer of July 7,1929-that it was South Africa that could claim to possess the most recently formed medical association or union; and, although its membership was limited to witch-doctors, although the "smelling-out-rod" was held to have more virtue than the stethoscope, the clinical thermometer, or even the $\mathbf{X}$-rays, and although an emulsion of pulverized gramophone record in water obtained from a railway-engine was believed to contain both a "voice" and a "go," enabling it to cure aphasia and every disordered motor function, yet might it not be presumptuous on the part of the profession to ignore them, when recalling the fact that, before Europe awoke to the significance of a bite from a malaria-infected mosquito in cases of general paralysis, the members of this union had learnt to apply it as a cure for this disease ?

However, one was on safer ground when looking no further back than 1649 for the germ of a medical society in our own country - the year in which, Sir Humphry said, "Ye Philosophicall Clubbe" began its meetings in Oxford. The Royal 
Medical Society of Edinburgh, Founded in 1737 , Charter in 1738, was within eight years of celebrating its bicentenary; it was still primarily for students rather than for the fully fledged; its latch-key was still in the speaker's possession. but alas! had not been used since his undergraduate days. Of those nearest to the Association's present place of meeting, the Medical Society of London, founded in 1773 , was the oldest. In 1805 it begat the Medical and Chirurgical Society, from which sprang, by union with several other medical bodies, the Royal Society of Medicine, with its twenty-five sections, including one for Neurology and another for Psychiatry. Then there was the Medico-Legal Society, before whom some of the legal conundrums which confronted this Association's work were often favourite topics. The activities, so potent for good, of that great body, the British Medical Association, were weekly before the profession, and it was in their palatial premises that the Royal Medico-Psychological Association had dwelling. They were fortunate in having present to-night its Medical Secretary, Dr. Alfred Cox, whose name in the work of that great Association was a household word, and whose constant strivings to improve the opportunities for good professional work were familiar to all, as was his ready help to a number of his hearers personally.

The value of the Royal Medico-Psychological Association was far-reaching. Fully and properly used, its membership was of the utmost service to the individual member, and, with the aid of the Press, as a disseminator of knowledge there was no more potent agent. Sir Humphry Rolleston had something to say about Edward Jenner and the Gloucestershire Medical Society. The speaker could supplement this by mentioning that Jenner, who was an ardent Freemason, was in the habit, before his Lodge - the Royal Lodge of Faith and Friendship, at Berkeley-was assembled, and before its doors were closed to none but Masons, of holding a "Lodge of Science," to which anyone interested was welcome, and at which many facts of importance to health were discussed and taught.

Before asking those present to drink the toast he would strike the note on which he desired to conclude. To that language, full of delight and charm, which so pleasantly greeted their ears when they crossed the Channel, English admittedly was so deeply indebted that our French friends would pardon a solitary tilt. His "grouse " was against their word aliéné, from which we derive our unfortunate, but he trusted moribund, terms "alienist" and "alienism." Too much and too long had the specialty been isolated from the main body of medicine. Happily the barriers, ab initio rotten and unsound, were now fast breaking down; and, in welcoming to-night representatives of other medical bodies, it was the desire that they should discern something more than an attempt to show hospitable courtesy. He wished them to credit us with a deep sentiment of unity and a fixed intention to seek help and strength from them, together with an earnest desire that our own work likewise might be sought in aid and not found wanting in value. It was brotherhood that bound, and friendship was the great chain of human society.

He submitted the toast of our "Allied Societies," and coupled with it the name of Dr. Alfred Cox, O.B.E., Medical Secretary of the British Medical Association.

The toast was pledged with enthusiasm.

Dr. Alfred Cox, O.B.E., in responding to the toast, said nobody could have been selected who could have done it with a better will-though someone else might have done it more skilfully - than himself, because there was no man in any association who had received more acts of kindness and more signs of willingness to cooperate than had he in his official position. He could not profess to speak in the name of those honourable societies which were mentioned by Sir Hubert Bond, but no doubt the members of those societies would wish him to say what he felt for his Association, namely, that they were very grateful for their hospitality and the kindness with which this toast had been received. The British Medical Association was allied with the Royal Medico-Psychological Association in many ways. In the first place, both bodies shared the same building, and, up till now, they had not quarrelled. Secondly, they had shared the same Librarian, and had likewise shared the names of some of the most honoured members of the profession. He need mention only three to show how close that bond of membership had been. There was their honoured founder, Sir Charles Hastings, who establisbed the Association in 1832, so that the centenary would be celebrated in 1932. He was a member of the Medico-Psychological Association. Sir Clifford Allbutt was also a member of this body. Another was a distinguished member 
of the profession who had more recently gone-Sir Frederick Mott. In addition, they shared some common interests, as both Associations were interested in the question of lunacy-law reform, and both had been putting in a good deal of hard work and spending much money in this connection during the last few years. They were now looking for some results. As the present company knew, the Royal Commission on Lunacy reported in 1926, and he supposed that, if those concerned were very good, in something like twelve years' time some results might be seen. He mentioned twelve years because he had been looking at the figures concerning Royal Commissions on lunacy affairs, and he found that twelve years was about the average time which elapsed between the issue of the Report and any practical result. He did not know where the blame for that delay lay, but it was not with the Board of Control. It was a very poor compliment for the people who put in the hard work implied by a Royal Commission if its labour were to be shelved and left, while Parliament was playing with many things which, to his mind, seemed to be of much less consequence. He could not hope to live to see it himself-(Laughter)-but perhaps the more junior members present might be at an Association dinner some night when a Minister of Health would proudly announce that he would bring in a Lunacy Reform Act. He, likc other speakers, had promised he would not be long, but his difficulty had always been how to sit down when making a speech of this sort. For many years he had been trying to learn bow to do it gracefully, and he had generally had to fall back on a story. Even in the presence of that prince of story-tellers, Lord Riddell-who was also a very good honorary member of the medical profession-he would like to tell a story which he believed Lord Riddell had not heard before, and that was saying a lot. During the war, he, the speaker, was Secretary of the Central Medical War Committee, and one of his duties was to find doctors for the Army. The doctors concerned all had a year's commission, but later on all except those from Ireland had to go for the duration of the war. The Irish doctors still kept up the one year. It was just after the Ministry of National Service had been formed that one of his colleagues rang him up and said a doctor wanted to see him. An Irishman appeared on the scene. He said to the visitor, "What can I do for you ?" The reply was, "I want some work." He, Dr. Cox, "Fancy bothering me with a thing like that ; there is work for everybody. Why don't you go to the war?" He said, "I have been there for a year ; just come out." " Go back then." "I'm not going back." "Why?" "When I qualified I did eye work. I have applied six times for eve work, and each time some damned Scotsman has got the job." He had been told that the Minister of National Service found work for everybody; he had been down to Caxton House, and found that the head of it was Dr., later Sir James, Galloway, another Scotsman, and moreover an Aberdonian, so he came away, feeling it was no good, and so came on to the speaker to see if he could do anything for him. There was a moral in that, but it was not for him to point it. This was one of the few societies that were not pervaded by Scotsmen.

Again he thanked the Association and the company for the way in which the toast had been received, and for the very enjoyable evening he had spent.

\section{“The Guests AND Visitors."}

Prof. George M. Robertson said that as no less than four were to reply to this toast, it had been intimated to him that his remarks in submitting it must be brief. The President, in telling him this, reminded him of the story of James Russell Lowell, the great after-dinner speaker. Lowell's friend met him one day in the street and asked him if he was going to speak at a great function which was shortly to be held. He replied that he was. The next question was, "How long will you speak?" "I suppose, about twenty minutes." Then his friend said to him "Take my advice, James, if sou don't strike 'ile' in five minutes, stop boring!" (Laughter.)

In the first place, the speaker wished to congratulate the Association's guests and visitors for their bravery in coming to dine with members of an Association with such a reputation as that of the Royal Medico-Psychological, a body having such a long and, to many, incomprehensible name. The public had a short way with them ; they called them "mad doctors." The members did not object to that very much, because everyone now knew that everything was relative, including 
madness. It was pointed out to an Aberdonian that it was a curious circumstance that the percentage of insanity in Aberdeen was very much higher than in other places, in spite of the Aberdonians being reputed to be very wise people, with very large heads. It was also said to be the only place where the late $W$. E. Gladstone could get a hat which would fit his head. An Aberdonian said it was easy to account for that : that the standard of intelligence was set so high in that city that any person possessing the slightest defect was at once conspicuous and he was regarded as insane, whereas the very same people, if they lived in London, for instance, would be regarded by the inhabitants as very clever.

A list of the guests had been placed in his hands by the Secretary; and as the speaker could not, in the short time at his disposal, do justice to each distinguished guest, he had tried to arrange them into categories, and he hoped his hearers wculd excuse him for this rude treatment.

First, there were the magnates, in whose territory they were all enjoying themselves : His Worship the Mayor of Westminster and the Chairman of the Middlesex

County Council. Next there were members of Government Departments : Sir Arthur Robinson and Sir George Buchanan of the Ministry of Health, Mrs. Pinsent and Mr. Brock of the Board of Control; Mr. Ross of the Scottish Office. There were also present representatives of the medical profession : the President of the Royal College of Physicians, the Dean of Westminster Hospital Medical School, and the Dean of the London School of Medicine for Women; the Secretary of the British Medical Association-who had just spoken-and the Editor of the British Medical Journal. There was one guest, however, whom he could neither compress nor classify, namely, Lora Riddell. He did not know whether to regard his lordship as an editor, or to put him down as a fluent after-dinner speaker, or whether to regard him as a Gulliver, or as just a very fine fellow. He thought that, after all, he must leave him as he was, a riddle! (Laughter.)

The Association was fortunate, also, in having present two foreign delegatesDr. Flournoy, of Geneva, and Dr. Pameijer, of Rotterdam. Two years ago the speaker formed one of a deputation of four representatives of this country in France. They were graciously invited to the British Embassy by Lord Crewe, who was then the British Ambassador in France, and all were greatly impressed with their interview with I.ord Crewe, who thanked them for coming to France, and said he appreciated very highly the good work which the deputation was doing. He added that the attention which they thus paid in this way to the French nation helped very greatly in the strengthening of the bonds cf friendship between Great Britain and France. In the san e way, and for the same reasons, those present appreciated the visit of these foreign representatives from Switzerland, from Holland, and from Germany, and thanked them for coming to this, the Association's Annual Meeting.

It was his duty to couple with this toast the names of four persons: Dr. Flournoy, who was the Lecturer on the subject in the University of Geneva and represented the Swiss Society of Psychiatry. His father had a female patient who could speak the language of the Martians. The existence of this language proved that Mars was inhabited! When flying across the Atlantic became a daily experience those who wished to take a trip to Mars would find a knowledge of the Martian language useful. That lady's family and all her friends believed in what she said, but he regretted to say that Dr. Flournoy, senior, had his doubts. He, the speaker, would like to know more, however, about that gifted and romantic lady. Dr. Pameijer was Medical Superintendent of Rotterdam Mental Hospital, and he had distinguished himself in the organization of social services outside the hospital. The Association was deeply indebted to him for having acted as guide to a body of physicians from mental hospitals in this country who had recently visited the mental hospitals of Holland, greatly to their own advantage. And he was glad to say that the physicians of Holland would return this visit, and he hoped the event would take place this year.

Lady Barrett was the Dean of the London School of Medicine for Women, and one of the most distinguished women physicians of her day. That hospital tolerated medical men, but admitted no male student into its precincts. For that there were, no doubt, very good reasons.

Sir Arthur Robinson was the Principal Secretary of the Ministry of Health, and it was to be feared that the pressure of work would prevent the bringing in of lunacy legislation in the near future, though, as Dr. Cox said, this was very much desired. 
He, the speaker, would take the present opportunity of pointing out that the Association was greatly distressed at the failure of the Nurses' Registration Act as applied to mental nurses. During the last five years the Association had trained over 5,000 mental nurses. These nurses were admitted to be the best-trained mental nurses in the world, yet only $5 \%$ of those mental nurses were registered by the State. He thought that the good sense and the guiding hand of the Ministry of Health was needed to put this matter right.

Dr. J. H. PAMEIJER (Rotterdam), in responding to the toast, said the Dutch Association for Psychology and Neurology thanked the Royal Medico-Psychological Association for the invitation to a representative to be present at its annual meeting. His little country followed the doings of this Association with great interest, and always with sympathy.

Sir Arthur Robinson, G.C.B., also responded. He said he was going upon the assumption that he would be the third to respond to the toast, but the unfortunate absence of Lady Barrett altered that. In a few brief words he would like to thank the Royal Medico-Psychological Association, on his own behalf and that of the guests, for the hospitality which had been extended to them this evening. They had had, as usual, an excellent evening; they had heard excellent speeches, and had enjoyed a good dinner.

He supposed he ought to say something in reply to the vigorous attack made by Dr. Cox, who said it would take twelve years to carry out the recommendations of the Royal Commission on Lunacy. Dr. Cox thought he would be dead before the recommendations of the Lunacy Commission were carried into law. But, as far as the carrying out of the wishes of a Royal Commission was concerned, the average period in recent cases was well under two years not twelve years, so that possibly Dr. Cox might live to see legislation on the subject of lunacy. (Hear, hear.) The Ministry of Health had enormous commitments, and the last accusation which could be made against the Ministry was that legislation was short. When one thought of slums, and de-rating, and local government and pensions, naturally some things got crowded out, but he could assure the Medico-Psychological Association and Dr. Cox that, so far as it was humanly possible, the Ministry of Health would do its best to see that this particular Royal Commission's Report would not lie on the shelf until it became too dusty.

The night was getting on, and no doubt Lord Riddell would tell the company some extraordinarily good stories-he knew one or two of them himself, but he would not attempt to rival his lordship. He thanked the Royal Medico-Psychological Association very cordially for their kind hospitality.

[Lady Barrett was called away during the proposal of the toast.]

"The Royal Medico-Psychological Association."

The Rt. Hon. LoRd RidDell said the toast of the evening had been entrusted to him, and it was coupled with the name of the President. He confessed that he came there that night with some trepidation. That morning a friend of his had said to him that he understood he was dining with this Association to-night. On being told that such was the fact, he asked whether he, Lord Riddell, having regard to his excursions on the subject and his references to sterilization of the unfit, had prcvided himself with a dagger-proof coat. (Laughter.) Of course he explained to the friend that, being a guest, he felt he was safe in such company. The other day he, the speaker, was called upon to give evidence for a man who was charged with driving to the danger of the public. The report of the case ran that so-and-so was fined forty shillings and costs, and that Lord Riddell gave evidence on his behalf and his licence was endorsed. (Laughter.)

This was a most valuable Association. He understood that it produced friendship among medical men who were entrusted with the task of looking after certain unfortunate members of the community; he had called them lunatics, but had been castigated for so doing. (Oh !) Secondly, the Association was very useful for research purposes; thirdly, for the exchange of views, and fourthly as a spurring point for Sir Arthur Robinson and other people. As a ratepayer, he regarded the proceedings of this Association with a certain amount of fear. He gathered, from the reports which had recently been issued, that it was proposed to spend thirty millions in housing mental deficients; he had not got the figures with him but he had looked into them. Some time ago he saw, in an Australian paper, a cartoon which represented a man who had brought an action under the Workmen's 
Compensation Act. He was portrayed as broken up, arms, legs and head. The scene was a lawyer's office and the man was depicted receiving a cheque and looking at it. The lawyer asked whether anything was the matter with the cheque. The man replied, "There is nothing the matter with it, but I was wondering whether it was you or me that fell off that blooming scaffold." (Loud laughter.) That was how ratepayers felt about all these expenses; they sometimes wondered whether it was possible for them to exist if such expensive accommodation was to be provided for mental deficients; they wondered what was to be done for the normal people, and whether normal children were to be penalized for the abnormal ones. One sometimes wondered whether it was right, that such a large sum should be spent in educating mental deficients, whereas a much smaller sum was expended in educating normal children upon whom the future depended. When he was in America he heard of a parson who had been called upon to deliver a funeral oration on a member of his flock, who had been a hard worker in the congregation. The oration wound up with the assurance that the man was happier where he was than he had been on earth. But a lady in the front pew, who was his widow, said, "I am his widow, I have been in spiritual communication with him, and he asked me to say that what you have said is incorrect." (Loud laughter.) The parson, who was very much annoyed, said, "I have been in the profession thirty-five years, and have delivered about 14,000 funeral orations, and this is the first time I have ever had any back-chat from the corpse.' (Much laughter.) He hoped the experts present would pardon this backchat from a ratepayer, who was likely to become a corpse if he was called upon to pay more in rates for the benefit of the mentally deficient. Those remarks did not seem to meet with much appreciation, but they were well thought out, and were, he considered, deserving of the most careful consideration. Everyone was very keen on his own job, and sometimes one did not see " the wood for the trees." But there was one advantage in being a mental defective or a lunatic, considering that when one had been made such, one would not be unmade without one's consent. He knew several lunatics who had a good deal of sense. They were living in comfort, some under gentlemen here. Under the beneficient provisions of our law a certain allowance was made out of their estate for their maintenance, in priority to their creditors, who would like them to become, as one might say, " unlunaticked " -(Laughter)-or " uncertified," but this could be done only with their consent, and they were much more comfortable where they were. They played golf all day, then went home in the evening to what in the former days used to be called an asylum. That well showed the advantage of living as a lunatic.

It had given him very great pleasure to be present to-night and to hear all the charming speeches which had been delivered. He was specially interested in what Dr. Cox said, as he was a special admirer of Dr. Cox; he was the best Trade Union Secretary in the country, a wonderful man! (Laughter.) There was a strong feeling about these Scotsmen, he agreed-he was himself a Scotsman. He, the speaker, hoped that those of his hearers who went in fear of the Scotch would remember that the English were really much the cleverer people, because they made use of the Scotch, while they themselves sat back and took the bulk of the profits.

But, quite seriously, this was a most admirable Association. He was delighted to see on his right this friend from Holland. It was a real pleasure to realize the high estimation in which our scientific people were held abroad. The truth was that we did not make enough of our clever people. We had here some wonderful scientific pecple, about whom most of the inhabitants knew very little unless they happened to be in the same business or profession or calling. When one went abroad to Holland and other countries one found how much such men were appreciated among those who really understood the subject, and who could, therefore, estimate their merits. This was one of those learned societies which combined practical with theoretical work, and which did a great deal to maintain the high position which our country had so long held in this particular province of medicine. It was a proud thought that we, with the French, were the first to initiate the modern treatment of lunacy. Quakers had many claims to distinction, but he thought their chief claim was the fact that they produced the first English-speaking doctor who appreciated the nature of mental disease. That was a great honour for the Quakers.

He asked the company to drink to the health of the Royal Medico-Psychological Association. The Mayor stumbled over the name badly; one never knew what 
mayors would be up to ; they did not concentrate enough. A journalist told the speaker the other day that he saw a paragraph in his paper stating-" Among the beautiful girls was the Mayor." He called the reporter to him and said, "What is the meaning of this?" He replied that it might be a grammatical error, but it was a fact. (Laughter.) He assured the company that the Mayor of Westminster always did his duty in that respect. That gentleman was telling him just now that he had been opening some garden fête, and he made a mellifluous speech on the occasion. By some accident it was attributed to the Mayor of Chelsea ; he, Lord Riddell, believed it caused a lot of trouble with the Mayoress of that borough.

The company must not think, because he had been somewhat frivolous, that he did not appreciate what an important toast this was, and what admirable work this Association did. He trusted that the Board controlling the Association would give serious heed to the proposal to build no end of asylums, mental homes, mental colonies for all these mental defectives; it was a very serious problem. How much more money was to be spent on the care and treatment of the abnormal? How much more was the country going to penalise the normal for the benefit of the abnormal ? Were people going to look at these questions without prejudice and without being bound by traditions? He had read very many reports, but he had not read one which was more serious than the one recently issued concerning mental deficiency - serious because of the facts it disclosed, but even more serious because of the extraordinary proposals it made for remedying these conditions at serious cost. It showed that the persons who wrote it did not properly appreciate the economic facts and the effects of those proposals upon our overburdened ratepayers, who were not mental defectives, though they might be well on the road to becoming so if rated to a greater degree. With this somewhat doubtful appreciation of the Association-(Laughter)-he asked the assembly to drink their health with much enthusiasm. He expressed the hope that during the forthcoming year they would most carefully study these mental deficiency reports, and find some means, in conjunction with Sir Arthur Robinson, of avoiding spending these large sums of money on people who were shut off more or less as if they were criminals. The Association had the advantage of possessing a most distinguished President-(Applause)-one of those specialists who possessed a large amount of special knowledge and of special experience, whose mind had not been warped, and whose vision had not been curtailed by the nature of his occupation. Dr. Nathan Raw was a fine example of a British medical man and a British man of science, and all in the Association were proud of him.

Dr. NAthan Raw (President) thanked Lord Riddell for the happy and felicitous speech in which he proposed the toast. The Royal Medico-Psychological Association was a great organization comprizing about 700 doctors. The duty of dealing with the insane was a difficult and trying one involving a good deal of disappointment but in many cases with successful results. The Association was anxious for legislation based on the Report of the Royal Commission, and were specially anxious to devote their energies to the prevention of insanity, by giving treatment in the early stages, and so avoiding, if possible, certification.

Members and guests then departed.

The musical interludes were provided by Miss Phyllis Everett (contralto), Mr. Will Gardner (humorist entertainer), and Mr. Victor Marmont at the piano.

$$
\text { MORNING SESSION.-THURSDAY, JULY II. }
$$

In the Hastings Hall, British Medical Association House, London, W.C. I.

The President in the Chair.

\section{Paper.- "Some Cases of Mental Disorder: A Patho-Clinical} Study," by W. M. Ford-Rorertson, M.B., Ch.B. (vide p. 618).

Dr. W. F. Menzies (Cheddleton) said that in discussing this paper it was a question of how much time one could spend in speaking about it. It was, he considered, one of the epoch-making contributions to this Association, and it was one of the first which definitely proved the influence of the anaerobes in focal infection. 
On the previous day many expressed regret that this was a medico-psychological association, so that it cut out of membership the bio-chemist. He did not think a man could be both. He admitted that Dr. Ford-Robertson came near to that combination, but life was not long enough to permit of both qualifications in the one man. The bio-chemist must have started as a pure chemist when he left school. He brought before the Association what he thought was a serious fault in its membership, namely, that it was impossible to elect as a member a pure chemist. He suggested that some effort should be made, such as in an associatemembership, to invite bio-chemists to join the Association.

With regard to Case 4 referred to in the paper, whom he had seen in consulting practice, the question at that time was whether it was dementia præcox or manicdepression. She was a public-school girl, an excellent athlete; the mother was alcoholic, and the father and mother lived in the same country house but did not speak to each other for years on end. When the girl got older she began to think about these things, and to adopt psychological defences. The head mistress wrote to her mother and said she had "gone off her head," and accordingly sent her home. There was much insanity in the family. It was thought to be a confusional case rather than of primary dementia. She was given a course of psychotherapy, but was later admitted to St. Andrew's Hospital. At school she had amenorrhœa. Her leucocytes were about ro,ooo. In her hysterical fugues she adopted the same drunken rollings of the head and body which had beset her mother when put to bed at night. Her psychology was manifested in the psychosis. She adopted the best defence she could. It threw an interesting light on the psychogenic origin of mental disorder.

Dr. Bedford Pierce (Commissioner of the Board of Control) said he had only heard part of the paper, but what he did hear had not only given him much pleasure, but it seemed extremely comforting as to the future of the Association, illustrating the excellent way in which scientific work was being done in the mental hospitals to-day. As Dr. Menzies had just said, it was most satisfactory to have a scientific paper of this nature, showing results of such careful scientific investigation.

Dr. Ford-Robertson asked those present for criticisms. It was impossible for him, the speaker, to make a criticism, but he would like to ask one question. Supposing every person in the room had an exhaustive examination made of his physical condition, what number would show in their body the micro-organisms which Dr. Ford-Robertson mentioned ? It would be interesting to know whether an average lot of people, of the same age and status, would be sufficiently free from the organisms in question.

Dr. J. R. LORD (Epsom) said that this paper was a real illumination to those members of the Association who had not appreciated how far the bio-chemical and bacteriological technique in regard to the examination of cases of mental disorder had recently progressed in this country. Dr. Bedford Pierce had said that a number of people in the general population might also show the same kind of bacteriological pictures that had been described. Dr. Douglas McRae who had worked with Dr. Ford-Robertson's father, had laid it down to him, the speaker, that it was not merely a question of a person having septic foci, it was rather a question of whether he was absorbing toxins from them. Whether or not he did so depended on his bio-chemistry ; in other words, it was a bio-chemical problem of defence. But that was not all. Bio-chemical defence was essential to health, even life. A toxin or a virus had a chemical constitution like everything else, and the destructive effects in the body in general amounted to chemical combinations which robbed the tissues of oxygen so that a state of anoxæmia resulted. If the individual was not capable of putting up this chemical defence there occurred what was commonly called septic or toxic poisoning.

It was with the view of ascertaining some of these basal factors that the Association's Research and Clinical Committee was established. Such problems could not be mastered by one person working alone. Someone with expert knowledge was necessary to direct and co-ordinate the work of many who had not that knowledge, and often wasted their time and energies through lack of such guidance. A right step had been taken in associating a bio-chemist with the Committee's activities by electing Capt. Mann as its Honorary Adviser in Bio-Chemistry. He did not wish them to discuss the question of opening-up the Association to non-medical members, but he thought, with Dr. Menzies, an 
associateship, with a strict limitation of numbers, might be established for which scientific workers would be eligible.

He wished to congratulate Dr. Ford-Robertson on a most instructive paper The speaker expected something of the kind, being aware of the fine work that gentleman was doing. He hoped the researches would continue, but of course without prejudice to other lines of inquiry, for though bio-chemical processes were the ultimate modus operandi of morbid mental states, biochemistry could not answer the question why such problems should arise.

The PRESIDENT, in bringing the discussion to a close, said be desired, first, to congratulate Dr. Ford-Robertson on continuing the brilliant work of his father. He offered his congratulations also to Dr. Rambaut, at St. Andrew's Hosptial, for having made it possible for these scientific investigations to go hand-inhand with clinical observations and treatment. At St. Andrew's there was an ideal combination: a laboratory, a pathologist, a first-class bio-chemist, a bacteriologist and capable clinicians and nurses. Thus one had had presented to them the whole picture. He hoped many institutions would follow Dr. Rambaut's example.

With regard to the suggestion made by Dr. Menzies and Dr. Lord, that biochemists should in some way be associated with the work of the Association, he was heartily in agreement. But it would be necessary to revise the Association's Bye-laws to effect this. Obviously if members were to makc scientific progress in the treatment of mental disease, bio-chemical observations must be included -observations such as had been so splendidly reported to the Association to-day.

As to the paper itself, it was difficult to offer criticism. It was true that many of the micro-organisms found in these patients were also present in everyone. Whether or not their toxins were absorbed and did great damage was for the observers and the bio-chemists to demonstrate. It was remarkable that there should be so many anaerobes, especially the Klebs-Loeffler. He would like to hear how Dr. Forbes-Robertson made his autogenous vaccines.

The case which had most impressed him was that described as a rapid toxamia. It seemed pretty conclusive that it was a direct infection by a superabundant dose of the lepto-streptothrix and that by treatment with autogenous vaccine those symptoms were alleviated. Many had written papers dealing with the association of mental and bodily disorders, and the two finest examples of this association were furnished by alcohol and puerperal insanity. Both, he considered, were obviously toxic infections. When the toxic infection had bcen overcome, the patient made a magnificent recovery.

It was possible to pursue this subject for hours, but he did desire to congratulate Dr. Ford-Robertson, from the chair, on what he considered a very brilliant piece of work.

Dr. Ford-Robertson, in reply, first wished to thank the President and other speakers for the very kind appreciation they had shown of his research. This kind of work was necessarily arduous and very difficult. One was faced with so many problems, and one felt that each step in the advance was by no means the end of the difficulties; the work was no more than at its beginning.

Dr. Menzies had made reference to the influence of anaerobes in bacterial infection, especially the last case. In mental patients there seemed to be a peculiar association between the oral aerobic group, such as Streptococcus anginosus and $S$. salivarius and other streptococci; mental patients seemed to harbour these organisms. There was the added factor of anaerobic infections, and it was the combination of the two which made it difficult to know where one stood in toxic xtiology: i.e., had the anaerobes a greater or a less importance than the other type of infection? Much work was needed in order to elucidate that problem.

Dr. Bedford Pierce mentioned control work. For $2 \frac{1}{2}$ years the speaker was Hon. Bacteriologist to Southport Infirmary, and he was also in private consulting bacteriological practice. He had carried out 300 to 400 intestinal examinations, also dental, tonsillar and resting-juice cultures, and had traced infections from mouth to colon. Further he had the opportunity in 200 cases of making this complete overhaul which he had undertaken in mental cases. One very striking fact presented itself. Out of that large number of cases he had thirteen borderline patients, two were under certification. The moment one encountered them, the anaerobe or leptothrix group came into prominence. Not only were those organisms found, but they were vigorous, in large numbers, and easily grown. 
Anaerobic bacteriology was difficult, and it was hard to get suitable artificiar culture media for these organisms.

As to whether these organisms occurred in non-mental patients, he had found some more, especially diphtheroids, but of the Hoffmann type, and much less metachromatic. There must be, he thought, a very gradual, almost insensible gradation between the non-neurotoxic and the neurotoxic person. His experience of such bacteriological work was that the organisms in non-mental cases were small in number and frequently incapable of subculture, but in the psychotic group the whole flora presented itself much more strongly and clearly. Since he had once more started bacteriological work on mental cases, many of them ill for a long time, he had been constantly confronted with the factor of anaerobic infection, and in most cases the organisms were very vigorous and easy to grow if the proper technique was applied.

Dr. J. R. Lord had mentioned the question of resistance, and what that gentleman said the speaker regarded as very true. It was not only a question of somatic resistance, the resistance of our tissues-for example, the tonsils-but in mental patients the factor of the susceptibility or otherwise of the brain and nervous system to infection must be of importance. For example, some of us escaped acute diphtheria, a known neuro-toxic infection, suggesting a natural resistance; of those, however, who contract the disease, many completely overcame it: nevertheless the difficulty of eradicating the Klebs-Loeffler bacillus from the tonsils was well recognized. The tonsils of many mental patients can be shown to harbour Klebs-Loeffler types of bacilli, but essentially as anaerobes. Infection of this kind when merely confined to the tonsils might have relatively little pathogenic significance, but if the same organism could be traced as infecting the whole length of the colon, their pathogenic importance must be greatly increased and their neurotoxic action taken into account. The degree of neurotoxic reaction in such cases must be partly dependent on the susceptibility of the central nervous system. The colon seemed an ideal nidus for these types of bacteria, but they could rarely be isolated except as anaerobes. They were extremely difficult to eradicate. The evidence he now had of chronic bowel conditions in mental disease was becoming increasingly interesting. He carried out, from time to time, X-ray examination by opaque meal and enema, and in tracing the course of the barium through the intestine it was astonishing to note in some the degree of spasticity of the colon, causing the meal to hurry through the small in testine. It was a reflex condition depending probably on the stasis lower down the bowel.

Environment was, of course, extremely important. The psychotic person, or the person with that tendency, was up against the difficulties of life, and if he had to face in addition the difficulty of an adverse internal environment, which from time to time rendered his nervous system thoroughly toxic, it was not to be wondered that he might break down. He was not trying to minimize the importance of psychology; he thought psychology would have its greatest field in the re-education of the patients to adjust themselves to their environment after they had recovered from their physical disorder. He thought there would be a great scope in the future for psychological treatment on those lines.

With regard to the Research and Clinical Committee, as the Honorary Secretary of a sub-committee of that Committee, he could only endorse heartily what $\mathrm{Dr}$. Lord had said, and how very important cooperation was. He, the speaker, did not think it was possible for every hospital to go upon the same lines in research on a comprehensive scale; that kind of research, however, must be a matter of team-work. He thought the needed cooperation could be secured by such a scheme as the Research and Clinical Committee had formulated, by which workers could meet and discuss the problems. The question of having associated with them a number of biochemists was, he thought, one of the greatest importance. He did not himself profess to be a chemist in the proper sense of the term and did not possess any degree in chemistry. In the various tests one needed to beware of pitfalls. The biochemist enabled one to ascertain the state of the individual's internal environment and the different mechanisms involved in the process of toxæmia, regression, and remission.

He was very pleased to note that the President congratulated Dr. Rambaut on his scheme. He, the speaker, wished to say how very much he was indebted to that gentleman for his constant kindness and help in everything he, Dr. FordRobertson, had done. The scheme for the reception hospital at St. Andrew's was 
Dr. Rambaut's own; thought out before the war, which delayed its realization. Dr. Rambaut in the interval visited many mental institutions both at home and abroad in his quest for the right lines to follow.

The President mentioned the question of the method of making autogenous vaccines. He, the speaker, made the vaccines in his laboratory and, with the anaerobic technique used, it was possible, after subculture, to get pure growths of diphtheroids and streptothrix which were washed off, killed by heat, and standardized. He had not yet ascertained whether they produced soluble toxins. He had proceeded on endotoxic lines. There yet remained an enormous amount of work to be done in that regard, as to the possibility of isolating some chemical substance which could be used in place of the vaccine. He was not himself satisfied with vaccines alone; he was under the impression that there was a subtle factor which was being missed. But he hoped that some other members of the Committee would take up the question.

He thanked them all warmly for their appreciation of his efforts, and for the way they had listened to a very long paper.

Dr. Menzies: Have you used the mercury pump the whole way through for the cultures and subcultures?

Dr. FORD-RoBERTSON replied in the negative; his method was more simple. $\mathrm{He}$ used sterile concentrated hæmoglobin as the enriching agent, adding it to the glucose agar. The oxygen was pumped out of the hæmoglobin by means of a Geryk pump for 12 to 24 hours before adding it to the media, until there was no residual oxygen left. While the agar was soft the tubes were sloped and as soon as set were plugged with sterile wool. Pyrogallol and $10 \%$ sodium hydroxide were then added and the mouth of the tube sealed with a cork and paraffin. The chemical action of the two reagents drew out any remaining oxygen in the tubes, and in 24 to 36 hours the tubes ripened, turning to a beautiful plum colour. By this change one was certain of using a strictly anaerobic media. It was with this media he had first studied his father's work. He had been able to perfect the technique and during the past six years he had been using it constantly. It was this method which had enabled him to make the bacterial isolations mentioned.

\section{PAPER.- "Charcot's Disease in Tabo-Paresis," by Gordon F.} Petnes, M.R.C.S., L.R.C.P., D.P.M. (viile p. 639).

Dr. J. R. LORD (Epsom) said there were some interesting features in the first case, particularly the fact that the onset of general paralysis was late, and of an acute kind. She had been a case of tabes for many years, and the Charcot disease of the spine had existed from early life.

He confessed that when looking through the literature, the causation of Charcot's disease seemed to be very obscure. He had had thoughts as to whether its occurrence might not be due to secondary infections, the syphilitic virus being the deteriorating factor which permitted of further invasions because of the lessened resistance which the syphilitic virus brought about.

The Charcot spine case gave cause for wonder. The skiagram showed that the vertebræ had almost moved right round. The absence of pain when these Charcot joints were handled was a remarkable factor, which, again, might point to a toxic condition and a destruction of the nerve supply.

The PResident asked whether there was anything else found post-mortem.

Dr. Peters: There was no evidence of any other disease.

Dr. T. SAxty Good (Oxford) asked whether the pituitary was examined in the three cases reported. A similar case had been published lately, in the Lancet, almost identical with Dr. Peters's second case. In the Lancet case the posterior lobe of the pituitary showed signs of disease. An interesting point in these cases of tabo-paresis and general paralysis was as to why those people developed mental symptoms. For instance, there were three cases admitted to the Oxford County Asylum in which it was known that the syphilitic infection was of very long duration. The onset of the mental symptoms in each case was within a week, and took place during the recent influenza epidemic. Of the three cases, one was still living, though he thought the end was not far off. Unfortunately, when the other two cases died he was unable to procure a post-mortem examination. It was interesting that if one took these cases of encephalitis which 
occurred in the influenza epidemic, or which took place in large numbers from any cause, one would nearly always find a paretic curve, though one could not find any evidence of syphilis.

He mentioned those two points, because recently his colleagues and he had been investigating the pituitary gland in these cases, with some rather interesting results. They were, however, too vague at present for him to put into words. What had always been of great interest to him was not so much how these patients got general paresis, but rather why the general paralytic had these extraordinary mental symptoms. In one of the cases mentioned to-day, in which there was acute loss of power, and loss of perception of place and time, there was confusion due to toxæmia. That also had been his own experience. He raised the point because he had had a similar case, and it was one of true Charcot's disease; he knew she had had primary optic atrophy for many years. After she became a definite tabo-paretic she gave birth to a child. She had malaria treatment, but it produced no good effect. She had a positive Sigma for both blood and cerebrospinal fluid. Also, there were definite changes in the pituitary gland.

Dr. Peters, in reply, said that in the cases he described the pituitaries were apparently normal to the naked eye.

The President, in the name of the meeting, thanked Dr. Peters for having read this most interesting paper, and for the complete and most careful observations it contained as to the appearances both before and after death.

[Interval.]

20. Visits.

AFTERNOON SESSION.-JULY II.

Members and their friends visited Springfield Mental Hospital by the kind invitation of the Committee of the Visitors. They were received by Mr. De Salis (Chairman of the Hospital), Sir William Lobjoit, O.F.E. (Chairman, Middlesex Mental Hospitals Committee), and Dr. and Mrs. Worth.

Parties were conducted round the hospital, and in the Hall there was provided a cinematograph exhibition of the circulatory system in action and of digestive processes.

Tea was served on the lawn of the hospital, and during the afternoon selections of music were discoursed by the hospital orchestra. A cricket match was in progress, which was watched with in terest by many members and guests.

A very pleasant afternoon was spent, for which all were grateful.

\section{[Adjournment.]}

MORNING SESSION.-FRIDAY, JULY 12.

In the Hastings Hall, British Medical Association House, London, W.C. r.

The President in the Chair.

Among those invited to be present and who attended were Miss Olga Nethersole. R.R.C., Dr. A. H. Macdonald, Dr. J. M. Roberts, Mrs. E. F. Pinsent, Dr. J. N. D Bosworth Smith, and Dr. R. H. Crowley.

21. Discussion.-“The Report of the Mental Deficiency Committee (Joint Committee of the Board of Education and Board of Control). Part I, General ; Part II, The Mentally Deftctive Child; Part III, The Mentally Defective Adult; Part IV, Report of Dr. E. O. Lewis on An Investigation into the Incidence of Mental Deficiency.'

(For opening paper by Dr. A. F. TREDGold, vide p. 584.)

The President said the Association was very grateful to Dr. Tredgold for having presented this subject so lucidly. The subject was now open to discussion. He was glad to see present Mrs. Pinsent, of the Board of Control, and a member of

LXXV. 
the Departmental Committee on this subject. Perhaps she would kindly make a few remarks.

Mrs. Pinsent (Commissioner of the Board of Control), replying to the President's invitation, said she did not come with any intention of speaking on the paper. Dr. Tredgold had given a most lucid explanation of the main features of the Report, and she would be very interested to hear the discussion by members of the Association. Possibly later in the morning she might make a few remarks on any points that might meantime occur to her.

Dr. W. A. Porrs (Birmingham) said he would like to thank Dr. Tredgold very much for his wonderfully clear exposition of the principal points embodied in the Report; what he had said in that exposition was absolutely beyond criticism. $\mathrm{He}$, the speaker would, however, like to direct attention to one very important matter.

Dr. Tredgold strongly emphasized the great importance of mental defect, and drew attention to the almost certain fact that its incidence had increased and was a grave social danger. The recommendation of the Committee that backward children and feeble-minded children should be dealt with by Education Authorities without any specific certification had much to be said in its favour, especially in certain districts; but it seemed to the speaker that a policy of taking them together, without clear differentiation, would possibly emphasize the difficulty which arose from the constant mistake of talking of well-marked defectives as border-line cases without making a diagnosis. The majority of medical practitioners never recognized mental defectives, but said of any such case, "It is a borderline case." Unless something was done to counteract this policy it would tend to increase the number of defectives, because if dealt with as borderline cases, they were not treated for what they really were. If the profession, or any section of it, accepted such a recommendation, they could only prevent it from doing more harm than good if at the same time they demanded that all medical practitioners should in future have some instruction in the subject of mental defect. Medicine was a curious profession. In the year 1913 an Act of Parliament was passed making it a duty for every practitioner in general practice to certify, when necessary, mental defectives who had to be placed in an institution; yet no provision had been made in medical schools for the instruction of medical students in the subject of mental defect, and the post-graduate instruction provided-the best of it through the instrumentality of Dr. Tredgold-was still hopelessly inadequate. A short time ago, in order to be assured that he was not making a mistake in uttering this statement-as at one time he was taken to task by someone who said he, $\mathrm{Dr}$ Potts, was ignorant of the excellent instruction given in mental defect, and that the majority of the profession were competent to diagnose a case-he asked many young practitioners if they had heard about mental defect. They replied that they had heard about it, but that was all they knew of it; they had never been to a lecture or clinic on the subject. Yet the ordinary public were under the impression that the medical practitioner, every medical practitioner, was qualified to recognize a case of mental defect. This danger was increased at present owing to the introduction of tests of intelligence. People thought these were sufficient to diagnose mental defect. The truth was that they were tests of intelligence, while mental defect was essentially a social incapacity, and might not be recognized by means of mental tests. Many of the tests were used by people who did not understand the subject, and recently he had seen several certificates of mental defect in which, as part of the certificate, it was stated that the defective had a mental age of 9 or Io years, and when he examined those cases he found that the mental age of some of them was 4,5 or 6 years-a serious discrepancy. The profession would not get on to the problem of mental defect until the education of the medical prufession in this very important matter was insisted on. (Hear, hear.)

Dr. J. CARswell (London) said he had had a depressing feeling for some time that he had lived in vain, but after hearirg Dr. Potts be was satisfied that he had not lived in vain. Dr. Potts had just said what he himself had never tired of saying for many years, so he would now merely state that he agreed with every word that gentleman had uttered, and perhaps "a little more so." Perhaps, some day, Dr. Potts would have the courage to express some extension of what he had said to-day. He, the speaker, was satisfied that the holy awe with which so-called tests of intelligence had been regarded in the past had greatly obscured the real estimate of the nature and quality of mental defect. 
Having made that personal confession, he would like to say a little more of a personal character. If instruction in mental defect was to be set going at all, it must be set going by those who were teaching medical students mental disease. While he was engaged in the most pleasurable duty of his life, he took the opportunity of using not only his position as a certifying authority and in the treatment of non-certifiable cases, but also his position of medical officer of the school authority and, through the session, he took bodies of three, four, or five students and showed them the methods of examination of children who were alleged to be suffering from mental defect. In that way he cleared his conscience of any reproach of having failed in the duty of showing medical students cases of mental defect as they occurred, and as he, to the best of his knowledge, tried to examine them and classify them. And he had reason to think that that duty was no altogether neglected even now, and that a great deal of work had been done in that way, and that if the medical man to whom Dr. Potts had referred had been trained in Scotland, perhaps he would have obtained more knowledge on the subject than he had obtained elsewhere. A practical scheme of that sort was possible in an area dealing with a million people packed together, as were the people of Glasgow, but it was very difficult in London, because much time would be spent in getting schools to do it. But that such an organization had to be built up was obvious enough.

He was rather at a loss, and he spoke subject to correction. He gathered that the idea of non-certifying applied only to some mentally defective children, and not to all.

Dr. TREDGOLD : It is suggested there should be no need to certify children in order that they may receive the particular kind of education that their case requires in a special school under the Education Authority.

Dr. CARSwELL: The other point was that this suggestion arose because in a substantial proportion of the children who had been certified as defective it was found at a later estimation of the condition that they suffered from defects which prevented their benefiting from the education supplied by the ordinary school, but that in the social sense they were not defective at all. He was glad he had lived to hear that that was now recognized. It was obvious enough to him thirty years ago. Again, he claimed that to a considerable extent he separated out that class of children from the defectives; and while pointing out that they might be taught along with the other children in special schools, it was desirable that they should be re-examined every sixth month, and the teachers given special instructions regarding them.

But that did not prevent him from supporting, very heartily, Dr. Potts's view that when a child was found to be making no progress in the ordinary school he should not be subjected to a special mental examination, but, simply on the word of the teacher, should be passed into a special school. He agreed with Dr. Potts when it was suggested that a child by reason of some mental incapacity was not getting the benefit he ought to from education in the ordinary schools, it was a not hazardous thing to leave it to the teacher to decide.

Dr. E. S. Litréjohn (Epsom) desired simply to ask a question as to the reason Dr. Tredgold gave for the abolition of the special schools. The work now carried out in them would be carried out in the ordinary schools; simply the name of the special schools would be done away with. But Dr. Tredgold said the law would not permit an extension of the special schools at present, and he, the speaker, did not know why.

Dr. TREDGOLD, answering Dr. Litteljohn, said it was a very important question, and it was gone into in the Report. There were various factors. One was the reluctance of school medical officers to certify children. Medical officers said, "I will not certify this child as a mental defective." It had been a factor in preventing schools being established. These factors, under the present state of the law, made it impossible to enlarge the special school system to an extent that would provide education for all the children existing. And there were further difficulties. As long as special schools had to be isolated from the rest of the school system, there were extreme difficulties about making proper provision in small towns. The Committee had calculated the population necessary to run a special school, and there were many areas in which there were not enough school children to start a special school. There were various considerations of that kind, also the fact which Dr. Carswell alluded to-that one-third of the 
children who went to special schools were certified as mentally deficient, and when they reached the age of sixteen they were no longer defectives. It was a great hardship that a child who was a dunce or a dullard should have to be certified as a mental defective in order that he should receive the proper form of education : it was a hardship when the child came to leave school and required employment. All the arguments were set forth and dealt with in the Report. He saw no advantage in retaining certification, but he saw many advantages in abolishing it.

Dr. A. H. Macdonald (Dr. Barnardo's Homes) said he hailed with delight the suggestion to abolish certification because he hoped this would benefit a large number of children who up to the present had not benefited by these special schools or classes and who ought to have done so. In the work in which he was engaged they had a large percentage of dull and backward children, and that might be because many of them had been "hit" before they came in. It was his duty to see every boy when he reached the age of fourteen. Soon after entering this work it struck him that something was wrong-that an injustice was being done to the child ; i.e., that the education provided in the schools was not benefiting a large number of the little children. Four years ago he took some care in examining all the children in the Homes, some 8,000 of them, and he concluded that there were 60 per thousand who ought to have gone through or ought to be in special schools.

And he had been interested to-day to hear the speakers who called in question the advisability of abolishing certification. He had found that there existed a diffidence among medical officers in regard to certifying these children, for the reason that there was held to be a certain stigma attached to it, and if that stigma was removed, more children were likely to be received into the special schools. More provision would have to be made if that suggestion were taken up. If certification were abolished there should ensue a great benefit to the children.

Dr. W. F. Menzies (Cheddleton) said he did not know whether at this late hour one was justified in spending much time on this Report; he could only take up a few points.

The Report was simply excellent ; it was the result of an enormous amount of work, and its findings were of such importance that his wonder was that it had not attracted more attention. All the efforts of those who had tried to get the Press of this country to take notice of such an important thing as mental illness and mental deficiency had met with no more than a lukewarm enthusiasm, to say the least. One must conclude that the reason was that it was not good " copy." One could not get the Press to report the subjects which were dealt with at, for instance, the Board of Control's Conference some few years ago, or to take notice of the magnificent work of Sir Hubert Bond at a more recent congress in recommending so many of these reforms. And, he repeated, it was probably all because it was not " copy." Yet when one moved among the general public who took an interest in these subjects without knowing much about them-he was speaking of the lay members of the public-they said, "What are the doctors doing about it ?" "What is the Medico-Psychological Association doing about it ?" Unless the Press gave them the opportunity, medico-psychologists could not influence the public. He did not see that much could be done unless the great newspapers brought these subjects forward in the public interest.

As to the proportion of mental defectives in the population, the Report mentioned 8 per thousand, but his own idea was that the number was at least i 2 per thousand. There were two methods which had been found very useful in ascertaining the proportion of mental defectives, and both were somewhat humorous. The first was: Had the man-or woman-passed the fourth standard when at school? If not, he or she was a mental defective! He was referring to such cases as had not some obvious physical defect associated with their mental deficiency, such as the intelligent epileptic or the person who was blind. The second, equally humorous, was that if a working man was not married by the age of thirty, he was a mentally deficient person. That remark was directed in an ordinary way to those who had to perform manual labour for a living. It was wonderful how safe it was! It was a different case in the moneyed classes, in which men could please themselves on such a matter and could pay for people to look after them. A poor man, however, could not pay for these things, unless he had a wife (laughter). Therefore the labouring population married for the wife to carry on the work, and, later, the children went to work and helped with the finances. It was therefore: 
argued that any man in the working class who could not get a girl to have him and marry him by the time he reached thirty was a mental deficient. Inducing a girl to marry a man whom she regarded as a fool might mean the marrying of mental defectives together. How often one found both husband and wife mentally deficient. That introduced an incomplete dominant. Most of the children of such marriages were bound to be mentally deficient. In his institution he had a farm labourer. Both he and his wife were mentally defective. In ten years there had been born five children who were mentally deficient, and the house was in such a state that no public authority could employ them. In the case of his institution out of r,100 patients, 250 to 350 had some mental defect. Some had an added psychosis, but not all of them, and, as he had said, he was inclined to think 12 per thousand was likely to be nearer the true incidence than 8 per thousand. In North Staffordshire one had one of the most interesting districts in the country, where the carboniferous limestone pushed itself through the secondary geological formations such as the new red sandstone, and where limestone caves abounded, some of them containing interesting remains, such as those of the cave-wolf and the cavebear, and in the later stages coins and ornaments, first Roman, then British. In the higher strata were the bones of Saxons who fled from the Danes. These things were evidences of an old and stable population, some of whose present-day descendants, until the introduction of char-a-bancs, had never seen a railway train. In going through and visiting people of that kind one noticed several features of interest. First, there was the great astuteness of the grandparents-most intelligent on the average; second, there was the fewness of the parents, and the third was the large number of mental defectives in the present generation. That meant that the old people had been accustomed to make a fair living, when times were not so hard socially; and it meant that as financial stringency increased, the populationthose who were sensible enough-filtered out of their native places and moved to the towns. It was surprising how many such families sent their defective children back to be looked after by the unmarried aunts and by the grandparents. The numbers were small, but he had come across them frequently.

The third point he wished to comment upon was sterilization. He did not wish to go back on the doctrines of Weissman and question whether bodily deformities were propagated, but there was no doubt that the whole population, perhaps of the world - certainly the civilized population-were, in regard to complete mental health, only heterozygous. If they were homozygous there would be no mental deficiency and no mental disorder; there would be no insane, and the population would die out, as so many had in the history of the world. The vast majority of people were heterozygous, and this mental deficiency was, luckily, and necessarily a recessive Mendelian factor. He admitted that many people refused to believe it acted as a simple Mendelian recessive. It was a complicated matter. But mental defect began in the embryo in some cases, while in some it did not begin until old age, and there was no distinction between mental defect and acquired mental illness; it was only a question of the stage at which the toxin was added to the inherent instability. And he did not suppose that any body of people would object to sterilization if it was going to do good. Those who spoke in this way were not sentimental; they merely said that the bulk of the people displayed a heterozygous dominant for sanity, and if mental dcficients were sterilized one could only get hold of those who procreated many children.

The vast bulk of mental deficients had, in times past, been able to earn a fair livelihood. The standard arrived at in this respect was from ros, to $f$ a week; if they earned more than $€ \mathrm{I}$ they were not considered to be of abnormal development. But now standards had risen. At the present time, when there was much unemployment, the mental defective had been cast out from employment, and there were now many more of them, who had been thrown on the Local Authorities for their support. It was a social problem, but no one would ever suggest sterilizing these somewhat subnormal citizens.

Another point was, was it desirable to be without mental deficiency ? Mental deficiency was an evidence of genetic variation and where genetic variation occurred one found variants from the mean in both directions. It was all problematical, but if one was going to hope for the time when there would be no mental deficiency, it would be hoping for the time when there also would be no genius. Variability was a necessity for all animal life. By doing away with it one would 
be doing away with the progress of the human race, and as long as there was a human race there would exist mental deficiency.

Dr. J. R. LORD said it had been suggested that this meeting, being representative of a varied body of opinion on this subject, might perhaps, before it dissolved, come to some conclusions and approve certain motions.

He would first, however, like to comment on one or two points which had been referred to that morning.

It had been a real privilege to hear somebody who was recognized as a great master on this subject. The speaker knew that Dr. Tredgold's time was much taken up, and his coming to read the paper was greatly appreciated by members. Dr. Tredgold had spoken of the importance of the subject of mental deficiency, and of the size and gravity of the problem. It was a point which he, Dr. Lord, had himself recognized, and he had done his best to get it appreciated by others. He had tried to provide adequa te opportunities for those members interested in mental deficiency to remain linked up in the Association with those who had to do with mental disease. He had assisted towards the formation of a Mental Deficiency Sub-Committee of the Research and Clinical Committee, which was doing good work.

Dr. Menzies had complained of the lack of interest shown by the Press on this subject. He, the speaker, had reason lately to complain of just the opposite. Some present might remember an inflammatory article in a Sunday newspaper headed "Lunatics on Parole," making the most atrocious charges against a wellbehaved and respectable section of the community. There was the "sterilizing" section-a noisy, irrational crowd whose creed Dr. Menzies in a few words had laid in the dust. This section was out solely to save expenditure-to take a short cut to a purely imaginary millenium-one of mental and social equality on a high plane. The mental case and the mental deficient likely to be harmless if free from confinement, were to be given the option of sterilization and freedom or life-long incarceration. He was putting it mildly. They called this "voluntary" sterilization. In the speaker's opinion what they all wanted to know was the causation of primary and secondary amentia. Only on this foundation could rational eugenic measures be taken. The Association had asked the Minister of Health to appoint a committee of inquiry on this matter.

Another point in this interesting subject which had struck him was the extraordinary similarity of the present position as to mental deficiency to that of 1828 in regard to mental disease. In 1828 the Poor-Law Authorities, i.e., the overseers of the poor, had control of the lunacy situation in their areas. They feared to meet the financial situations necessary to the proper care and treatment of those mentally afficted, i.e., build asylums. It was more economical to keep such persons in workhouses and local prisons. If one could find a private hospital to take them at a still cheaper rate, they sent them there, and only then. That was the reason Lord Shaftesbury, when he took the matter up in that year, applied pressure in the only possible way he could, and that was by the intervention of magistrates with special powers and duties-a matter he, the speaker, would have to speak about at a later session.

The other point, mention of which he welcomed, was the presence of high-grade mental defectives in mental hospitals. The mental hospitals would be glad to be rid of them. They were the people who gave rise to articles in the Press of wrongful detention, and when at liberty, often circulated imaginary and lying accounts of their treatment during confinement. The Press did not appreciate that those people were really mental defectives, and that some mental disorder had made certification under the Lunacy Acts necessary. In many instances, however, when these superadded symptoms had abated it was impossible to get them admitted to certified institutions, so they had to be discharged.

A futher point was concerning the lack of a sound education of medical students in psychiatry, which included mental deficiency. The National Council for Mental Hygiene had taken the matter up strongly. That body pointed out to the General Medical Council the fact that the medical practitioner was enjoined by law to act as if possessing this knowledge, and yet there existed few facilities for its being acquired. Arrangements had been made with the Fellowship of Medicine to establish such a course, and extensions on those lines would no doubt come in due course. As to medical students, the clinical instruction they received in mental hospitals could be enormously extended and improved if the 
medical schools desired. In the case of the London (Royal Free Hospital) School of Medicine for Women and Horton Mental Hospital this had been done. Why should not other medical schools follow suit ?

He ventured to propose the following motions :

"That the Royal Medico-Psychological Association, being deeply concerned " with the evidence in the Reports of the Joint Mental Deficiency Committee, the "Board of Education and the Board of Control regarding the number of mental "defectives in the country, the insufficiency of provision for their education and

"training and the inadequacy of measures for their care, supervision and control, " strongly urges upon His Majesty's Government the necessity for action being "taken without delay.

"Those actions are: (I) To provide suitable educational and training facilities " for all mentally defective and mentally subnormal school children; (2) to provide "sufficient treatment, school and institutional accommodation for those in need of " these forms of care, and to provide adequate means for the protection, care and " supervision of those not in need of institutional care: (3) to set up a Royal

"Commission for the purpose of making full inquiry into the causes of mental

"deficiency in its relationship to abnormal mental conditions and to social " problems, and to any measure by which it might be prevented."

"Further, that a copy of the above resolution be sent to the Prime Minister, "the Minister of Health, the President of the Board of Education and the

"Chairman of the Board of Control."

He submitted these to the meeting.

Dr. E. S. LitTEljoHN (Epsom) said it gave him much pleasure to second the motions.

Sir Hubert Bond (Commissioner of the Board of Control) said that the reason he had not spoken, so far, was that he came to learn; also the matters he had wanted to speak of were not yet sufficiently digested in his mind. He was very glad to have been present to hear what had been said. He was sure all those present appreciated the immense importance of this Report which was being discussed, and none more than himself.

But when it was suggested that members should assemble to discuss this Report, he did not know there would be any proposal to submit resolutions to the meeting. Moreover, he was not sure he had sufficiently grasped the purport of the resolutions; his feeling was that they needed to be before one in writing in order that their force might be accurately apprehended. Against one of them he would however, venture to speak. He was a disbeliever in the efficacy of a Royal Commission for the purpose of inquiry into the causes of mental defect, or, in deed, of any other disorder. He suggested to the members present, for their consideration, that such a recommendation was unwise. A Royal Commission, in his view, would not hasten progress in this matter.

Dr. LORD replied that it was felt that if the meeting were able as a whole to arrive at definite conclusions, it could express them by resolution, and it was to suit that eventuality that these motions had been drawn up. It was open to those present to suggest amendments.

Dr. TREDGOLD remarked that much could be said in support of Sir Hubert Bond's point of view, but he also thought much could be said in favour of this Association expressing its opinion in this definite way; it was a very important body in matters of this kind.

He had given no more than a brief summary of this Report. There were a large number of mental defectives-children and adults-for whom no proper provision was made, either in the matter of schooling, training, supervision, or care; and he felt sure that even those in Government situations and Government offices would realize that unless the public took some steps to stir them into activity, nothing would be done, in spite of this Report ; there would be successive Royal Commissions until " the crack of doom." The only thing which cut any ice was when the subject was taken up by the Press and by important bodies like that under whose auspices this discussion was being held. He had carefully read the suggested resolution, and it seemed to be drafted in very general terms-in terms, indeed, which he thought anybody might support. Therefore he strongly urged the meeting, if it approved of the words submitted, to vote for the resolution. He held definitely that an Association such as this ought to give its views on such an important matter. No one, for instance, 
could find fault with the preamble: "That the Royal Medico-Psychological Association, being deeply concerned with the evidence in the Report of the Joint Mental Deficiency Committee of the Board of Education and the Board of Control regarding the number of mental defectives in the country, the insufficiency of provision for their education and training, and the inadequacy of measures for their care, supervision and control, strongly urges upon His Majesty's Government the necessity for action being taken without delay." That, he thought, the Commissioners in Lunacy would heartily welcome. The resolution went on to say more about them. [Reads]. It was No. 3 that Sir Hubert Bond objected to, namely, the suggestion of an inquiry by a Royal Commission. To some extent he shared Sir Hubert's dislike of Royal Commissions; a Royal Commission was a cumbersome piece of machinery, and any result from it was a long time in coming. At the same time it had certain advantages. It was the form of inquiry for which the country would probably have the most respect. Other forms of investigation were by a Departmental Inquiry, or an inquiry by the Medical Research Council, or something of the kind. He thought the country would distrust any inquiry by the Medical Research Council; he would himself. ["Why ?"] He had seen what happened in one or two such inquiries, one a rather recent one, which had something to do with ultra-violet light, and the Report seemed to him to be somewhat unbalanced. It did not increase one's respect for reports emanating from that quarter. Departmental Committee enquiries were always open to a certain amount of suspicion, because he had heard of a certain jealousy between one Government Department and another. There might not be much truth in that, but the suspicion rather robbed such an inquiry of the great authority it ought to possess. That left one with the Royal Commission form of inquiry, and that commanded as much popular respect as any form in this degenerate age. And it had the advantage of being able to spend money, and could be constituted on a wide basis. However, if desired, the wording of (3) could be-" institute full inquiry into the causation of mental deficiency in its relationship to social problems and any measures which might be preventive."

Sir HUBERT Bond pointed out that there were now less than a score present. Should not this matter be referred to the Council of the Association? The recommendation for consideration to be given to it should emanate from the Council.

The President said the meeting would be perfectly in order in sending up a resolution if it so decided. After all, this was the Annual Meeting of the Royal Medico-Psychological Association, and gave and did not take instructions from the Council. Expressing his own view, he thought the very general terms of the resolution were such that no one could find fault with, but he was inclined to agree with Dr. Tredgold's alternative to (3), that instead of advising the setting up of a Royal Commission, the meeting should simply say, "institute a full inquiry." In any case it would be a very long, laborious and difficult inquiry, and, moreover, there was not very much possibility of another Royal Commission being set up on mental matters for a long time, and already a Departmental Inquiry on this particular matter had been asked for.

Therefore, unless any further objections were expressed to the terms of the proposed resolution, he would put the first and second divisions, with the addition of " young adults," and in the third division, instead of " a Royal Commission," " institute a full inquiry."

Dr. LORD, as Acting General Secretary, and speaking on Sir Hubert Bond's point, said the Council of the Association had already expressed its approval. He had previously mentioned this. At its last meeting a letter was sent to the Ministry of Health asking that a Departmental Committee of Inquiry into the causation of primary and secondary amentia should be appointed. The present meeting was the annual one, and could intimate to the Council what its wishes were on any matter.

The President then put the resolutions as amended to the meeting, and they were carried without dissent.

He expressed the Association's deep gratitude to Dr. Tredgold, and to those who had taken part in the discussion.

[Interval.] 
AFTERNOON SESSION.-JUIY 12.

The President in the Chair.

22. Paper and Discussion.- "A Modern Approach to the Problem of the Admission of Mental Patients to In-Patient Treatment," by J. R. LorD, C.B.E., M.D., F.R.C.P.E. (vide p. 596.)

The President said the meeting had listened to a wonderful paper-what one would expect from Dr. Lord. It was very original, and supplied something to think about. He invited contributions from any who had ideas on the subject, and especially from any who had had wide experience.

Dr. J. CARSwEll (London) said he offered no apology for being the first to rise to discuss this important paper, because if at that morning's meeting he was glad he had lived so long, he was more glad that afternoon. Indeed, Dr. Lord had surprised him. While the opener was quickly uttering the word "sociological," he, Dr. Carswell, thought he might stumble on the word "socialistic." Had he done so, the speaker would have gone to Downing Street and asked to see Mr. Ramsay Macdonald, and would have asked that Dr. Lord be made a Peer of the Realm !

He asked whether Dr. Lord was not a little " crass" when he made the comment about safeguarding patients from wrongful admission and detention after they got into asylums?

Dr. LoRD : At the Edinburgh meeting in 1927, Prof. George Robertson suggested that the solution of all our difficulties in England regarding such safeguarding was to add to our English Lunacy Act that clause in the Scottish Act which permits a patient after coming into a mental hospital to apply for a separatc examination by two independent practitioners, who shall declare whether he shall be released or shall stay. This proposal was brought up at the Select Committee of 1877 and rejected, so it was not a new proposition.

Dr. CARSWELl, continuing, said he was glad to have an opportunity of removing from Dr. Lord's mind any idea that what Prof. Robertson put forward was in any sense the Scottish opinion. Prof. Robertson must have been speaking at large on that occasion, as he sometimes did, in booming that rather obscure and self-enacting provision, which had never been a cure for anything in the world.

Before he, the speaker, became a Commissioner, he had earned two or three fees by being appointed by the Board in Scotland to examine cases under that provision. He hoped $\mathrm{Dr}$. Lord would not persist in saying that this was a suggestion coming from Scotland. In Scotland they had very much more to say on the subject. $\mathrm{He}$, Dr. Carswell, had lived through what Dr. Lord was pleading for since 1878 . He had not been a medical officer long when it was impressed upon him how absurd it was that patients should come right into the asylum who had never had the slightest care for their malady, and were simply seen during a hurried morning's round by parish medical officers, certified, and within a few hours bundled into the asylum. It seemed so absurd that he dreamed dreams; he dreamed that some day all this would surely end.

Then it happened that he was transferred from purcly asylum work to parochial work, with the special view to looking after these cases of alleged insanity. He knew the "ins and outs" kinds referred to by Dr. Lord; they would disappear, not by psychiatry, but by the humanizing of administration. The Local Government Act of 1929 was one of the finest things which had been done for administration in connection with mental and physical diseases, and it marked a great epoch in the progress of medicine. Many a time he had tried to get patients certified so that they might cease this wandering into parochial institutions and into the street. But they could not all be certified; they had their wits about them too much for that, and perhaps not more than a tenth of them ever reached an asylum ultimately.

From his experience he did not agree with that paragraph in the paper in which it was remarked that $50 \%$ of the coming and going cases ultimately landed in the asylum. They were, however, a perpetual burden to everybody who had a thought for them, and that type of patient, when once he was in an asylum, generally made himself fairly disagreeable. 
So it was obvious that something had to be done to treat patients without certification, and when he said recently at a meeting of the Parliamentary Committee that it was necessary to be bold in this matter, that the Association must proclaim itself in favour of the abolition of certification, he meant that the justification for every rational step suggested for the early and better treatment of the insane had as its basis the view that certification stood in the way.

That there were cases, as Dr. Lord had pointed out, in which some sort of authority for detention was necessary, was undoubtedly the case. The so-called "non-volitional" case-it was an ugly word-was in this category. Once one admitted (and he was speaking from his experience as a Scottish Commissioner) the principle of the voluntary admission of a patient to an asylum, one had to recognize the fact that the day might come when that patient would be less volitional, and less clearly apprehend what he had done. In practice, the Scotch Commissioners - with very few exceptions-simply left well alone. They found a man lying in the third stage of general paralysis of the insane, who had entered the asylum as a voluntary patient, and they said that so long as the medical superintendent chose not to have him certified, he could remain not certified. He did not know what was the practice in England, but he had heard it stated that the certification of such a case was recommended by the Commissioners, and, that being so, some medical superintendents were prone to have such patients certified, to forestall an order to do so by the Commissioners. In Scotland there was a friendly understanding between Commissioners and superintendents which was hardly possible in a larger country like England, and the Scots Commissioners left more to the discretion of the superintendent than the sister body in England.

He thought that perhaps Dr. Lord would have referred to a provision in the Scottish Act of which the Scotch were rather proud, namely, "Certificate G," whereby a single practitioner could place a patient (naming him) in care. It ran : " I, G. C-, being a medical practitioner, place A.B-, who is suffering from temporary mental disorder, not of a confirmed character, in the house of J. B- for a period not exceeding six months." That case was not reported to the Board of Control; it needed no justice's signatures or sheriff's order. The legality of the procedure had never been disputed. He was of the opinion that if it did come to a decision of the Court, the Court would probably hold that such a certificate only protected the keeper of the house from the pains and penalties attached to the keeping of a lunatic as a source of gain, and conferred no authority for compulsory detention. He was aware that Prof. Robertson held a different view. But in Scotland they were lucky, for they did many things which were practically outside the law which the Board of Control in Edinburgh fell in with, because it was the best thing to do. There was also the question of the function of the Sheriff, who was a trained lawyer, usually of high standing. In some cases he was a K.C. In a place like Glasgow there were six or seven sheriffs. The question whether granting the order on the two medical certificates produced to him meant he was acting administratively or judicially had never been settled. The former was the view generally held. The sheriff never saw the patient, though it was in his power to do so. Neither did he call other evidence. In an experience extending over many thousands of cases he could only recall one instance in which a sheriff refused to grant an order. In the year 1889 Brudenell Carter's Committee of the London County Council produced a report recommending the establishment of a special hospital for acute cases to be admitted without certification, which was approved by that Council, and his, the speaker's, Council in Glasgow, agreed to the setting up of a similar institution for early cases. That came to pass, and in 1914 a psychiatric hospital was built where teaching was carried on and patients admitted without formality. The General Board of Control and the Local Government Board in Scotland approved of it, and the system had worked so well that to-day there was no mental patient reported to the Local Authority in Glasgow, that went direct to the asylum. All patients had the benefit nowadays of probationary hospital treatment, under two skilled psychiatrists, in two such hospitals in that city. If patients were certifiable they were certified; if they were not certified they went home ; their names were not reported to the General Board of Control The hospitals always kept in touch with the Board of Control, who visited once in six months, and sent in an informal report to the Local Government Board, and in that way all authorities interested were acquainted with what was going on. Under the new Local Government Act of 1929 all this work would be 
transferred to the municipal authority and there would be much plainer sailing; it would be all part of local authority administration throughout the country. Early cases would be dealt with as infectious cases were and not certified. Nobody would ask why. Their cost would be met out of the rates without reference to the Lunacy grants.

One was glad to see a missionary in England arising, even at a late date, and he believed the Scotch had established much the same system which Dr. Lord had so eloquently described. No doubt adaptations and differences were involved, but Dr. Lord had shown the way. He was glad that advantage would be taken -as it certainly would-of the new Local Government Act in placing cases of incipient insanity on the same basis as ordinary diseases, and Dr. Lord had done well at this juncture in emphasizing this matter.

He must say one thing of a controversial character. All this might lead to the aggrandizement of the Medical Officer of Health, and an attempt on his part to control asylums, in the same way as he now controlled infectious diseases hospitals. He did not think members need be afraid of that. Dr. Lord's paper implied some adjustment of that relationship of a beneficial character. He was glad the paper had been contributed and would go on record.

It was a matter of great personal gratification to the speaker that Dr. Lord had been well and vigorous enough to seize this opportunity of laying down the basis for rational discussion of a new era in administrative psychiatry which was undoubtedly being entered upon, and to the further advance of which the paper they had just heard would largely contribute.

The PRESIDENT asked whether the patients in the Glasgow hospital referred to had full liberty to leave when they wished.

Dr. CARSWELL: Yes.

The President: Whatever their mental state?

Dr. Carswell: If their mental state demanded it, they were certified; there was no other way open.

Dr. C. A. Mortlock-Brown (Braunton, N. Devon) said she wished to thank Dr. Lord for speaking clearly and for his frank exposition of the subject. His paper was so full of matter that she felt unable to comment on it efficiently in the space of a few minutes, but it seemed to her he rather assumed that everyone dealing with mental patients had complete knowledge of the disease process involved, and that all were actuated by the highest and most disinterested motives ; that all dealing with these cases were, in fact, endowed with supreme wisdom and an all-enveloping love of humanity. If that were the case why should any laws and rules be needed to prevent abuses? As she had said, she could not attempt to comment on Dr. Lord's clever paper at all comprehensively, but would like to touch on two or three of the points he had raised.

As regards judicial intervention, she knew there was considerable disagreement on the question whether the same practice and procedure, in every particular, was to be adopted in case of both paying and rate-aided patients. She thought the most sensible compromise was that the magistrate's visit to the patient be optional in all cases.

Notification was no less a stigma than certification, but certification was preferable in that it entailed a personal guardian or protector whose duty it was to see that the patient was cared for and facilitated the safeguarding of the patient's possessions. Thus her objection to doing away with certification was that it left the patient unprotected. In her opinion it would be entirely wrong for a patient, whether non-volitional or involuntary, to be sent to a mental hospital without reference to his relatives, and continuation certificates should not be made without reference to the nearest relative.

She had not Dr. Lord's high opinion of local authorities, but thought that if laws were just these bodies would carry them out.

In conclusion she said she was opposed to legal insanity extending its present boundaries and to mental hospitals admitting those who were not legally insane, such as voluntary boarders. If institutions were desired for incipient cases she saw no reason why institutions could not be established for incipient cases and limited to them. She wished to thank the Association for permission to be present and to hear Dr. Lord's paper.

Dr. W. F. SAmuels (Federated Malay States) remarked that Dr. Lord had thrown out the suggestion that the meeting might like to know what had been 
done on this question in other countries. In the Federated Malay States years ago the procedure was that if a person did something extraordinary he was taken up by the police and brought handcuffed to the magistrates, and charged with being a lunatic. If there was a "lunatic ward" in the general hospital, he was remanded there. The medical officer might certify him on the next day and return him to the mental ward. If not he would again be put in the dock, still handcuffed, and the magistrate might, or might not have him certified. A man might in this way spend two or three weeks in going backwards and forwards from hospital to court, each time appearing in handcuffs, before he was sentenced to be looked after.

In 1922 an enactment was passed by which the intervention of the magistrate was done away with. The person was brought to a medical officer, and either certified as a case for care and treatment in a mental hospital, or as one needing care and observation at home or he was set free. By this alteration in procedure publicity was almost entirely avoided.

Friends could also bring a mentally afflicted person to the medical officer of the mental hospital for treatment without certification. If at the end of three months treatment was still considered necessary, the Board of Visitors sent a recommendation to that effect to the local magistrate, asking that the patient should have a further three months' treatment. The magistrate could, if he wished, visit the hospital and issue an order for detention.

The enactment also made possible the admission of voluntary boarders, and accordingly a number were admitted. It gave the superintendent authority to discharge a patient if he thought fit to do so, and the patient therefore did not have to remain in hospital until a meeting of the Board was held. The patient could also be discharged on trial.

So far the new procedure had worked very well, and patients' friends were now much more willing to bring their mentally ill relatives forward.

Dr. A. A. W. Petrie (Banstead) said he was very much in agreement with Dr. Lord. Psychiatrists generally agreed with many of his points, and realized what a tremendous opportunity the new Local Government Act had given them for early treatment in the way to which both Dr. Lord and Dr. Carswell had referred. Obviously in a large administrative area it was easy for the local authority to make such provisions. In the later stages mental hospitals could provide the necessary treatment.

Dr. Lord had pointed out how half the problem was economic, and how broad the problem was, and how it was hoped that it would be more readily dealt with by the unification of control which the new Act gave, instead of that control being spread over a number of bodies and tackled piecemeal and in different ways as in the past.

Dr. Lord had said that the Local Government Act of 1929 gave psychiatrists many things they had been asking to be given by legislation. That was agreed.

It was also agreed that one should aim at treatment without certification, which was putting it in the briefest way. That covered the voluntary case; and it was hoped that the law would permit them to deal with non-volitional cases in the same way. There was only one point in the application of that permission in which a little caution was necessary; it was that when the amenities of mental hospitals were known, it might be found that they would require to accommodate five times as many patients as at present. That, therefore, was a point which needed attention.

While he agreed to a large extent with all that $\mathrm{Dr}$. Lord said about the Local Government Act, he believed that gentleman was asking for more than was likely to be granted. He, the speaker, favoured modesty in demands, and asking only for what was likely to be given, as lawyers had a great idea that they, the lawyers, should have a final say in these matters. It had been pointed out that one of the necessary things in connection with the admission of patients was the justice's order. He, the speaker, thought the compromise by which medicine could bes approach the law when it demanded its rights, was that any patients or their relatives should be able to demand that the case be investigated by a justice and an appointed certifying medical officer. But if patients and their relatives did not demand that, the psychia trists could continue to treat on voluntary lines as suggested by Dr. Lord. That would cover the voluntary case, as it was known to-day, and would also cover the non-volitional case. And one must remember the relatives because sometimes relatives, particularly in the involuntary or unwilling type of case, provided three-fourths of the objections and caused three-fourths 
of the trouble. In fact if one were dealing with cases on a voluntary basis, whether they were voluntary or non-volitional, it was necessary to have these patients and their relatives satisfied. If this were stipulated, then Dr. Lord's scheme might prove successful. One could not have these legal investigations and inquiries ad lib., because the paranoiac, for instance, would keep people indefinitely engaged. If an individual or his relatives stated that he was not in need of care and control as an in-patient, and if detention was not thought necessary, he would go free. He thought that the law would demand something, and what he had suggested was the simplest way of meeting the law's requirements.

Dr. Alexander Wal. (Epsom) said that the discussion on this interesting subject had been thrown open to two classes-those who had a wide experience, and those who had original ideas on the subject. That being so he was not sure whether he was in order in rising to speak-(Laughter)-but with the President's permission he would like to ask Dr. Lord's help in elucidating one or two. points.

In so far as Dr. Lord had made proposals as to certification which were not common ground, which were not among the things this Association had asked for all along, he gathered there were two outstanding points. One was that Dr. Lord insisted on an increase in the local authority control of the admissions to in-patient treatment and afterwards for all time or at least during the first three years, rather than that this control should continue to be exercised by a central body as at present. But the speaker was not clear how that would be reconciled with the provisions of the new Act, which tended to diminish the local control and increase centralization. The Poor Law guardians disappeared, and the authority for all these purposes, outside the towns, was the county, which was a very large unit.

Dr. Lord mentioned care being exercised by local people who might know the patient intimately; it was almost impossible for that to happen when the unit was an entire county. It was true that in rural areas there would be Guardian sub-committees of the public assistance committee of the county council, but in London, as far as was known, there would be no such provision, and the entire care and treatment of the insane would fall on the Hospitals Committee of the London County Council. The infirmaries would not necessarily be associated with particular areas, they might not be on a territorial basis. Therefore he did not know in what way the new Act could be said to proceed in the direction indicated by $\mathrm{Dr}$ Lord.

The other proposal was that instead of justices there should be a body of citizens of repute, who would interview the patient from time to time, and would confirm or continue the order for his temporary detention. The speaker submitted that justices of the peace, as at present constituted, were such a body of repute ; they were not persons who had been chosen for their legal training, nor were they high judicial personages sitting on an Olympian bench; at present they were persons chosen from both sexes and from all classes, and most nearly corresponded to the kind of body which Dr. Lord evidently had in mind. En

The alternative would be to give these functions to the local authorities themselves, i.e., members of the same authorities as were controlling institutions for the insane-in other words, the visiting committees. If justices of the peace and members of the visiting committees were excluded, he did not know where one would find the " reputable citizens."

Another point was that Dr. Lord spoke about the necessity for these continuation orders for the first three years, after which there would be something corresponding to certification, which $\mathrm{Dr}$. Lord appeared to regard as a more or less permanent measure. It was true that the popular idea of certification was that patients were certified once for all and put away, but was it wished that this view should go out as being held by this Association? Surely the certificate, as at present, would be a temporary document lasting for a year and having to be renewed from time to time by some authority, whether that body were the Board of Control or some other. Therefore he wanted to know how the renewal at the end of the three years would differ from the periodical renewal of the certificate which was given at present.

Dr. LORD, in reply, said he could only deal with some of the points raised in the discussion. Regarding Dr. Walk's remarks, he, the speaker, thought be had made it clear that the objection to justices interfering in the admission 
to in-patient treatment was that it associated mental disease with police-court work and wrong-doing. Similar action in physically sick cases did not involve any such association; neither was such association involved in the admission of voluntary cases of mental disorder. If some public sanction was required in the admission of the involuntary case-and in his opinion it could not be denied that there were grounds for such sanction-let it by all means be free from this taint. The panel of "approved citizens" he had suggested, or per contra for public assistance cases, and if the local authority was so minded, the visiting com. mittee of the hospital or a panel of selected members of the mental hygiene or appropriate committee with, if necessary, co-opted members, might, and probably would, be composed of some magistrates, but they would not act in a judicial capacity; others, whether justices or not, might be doctors, lawyers, parsons, butchers, bakers or farmers, or any citizen of common sense and good repute in whom the local authority and the public had trust and confidence to deal fairly and justly in such circumstances. They were for the purpose of seeing fair play before admission of the unwilling case. They had to satisfy themselves that the patient's liberty was not being unduly sacrificed and the human side not forgotten in the stress of professional zeal. They would be guided, but not dominated by the medical opinion.

He was glad Dr. Walk had called attention to this point, for it had given him the opportunity of clearing up any misunderstanding. As to sanction for detention of involuntary cases after admission, he really wanted those who gave this sanction in both public and private mental hospitals to be as interested in these cases at the end of the tenth year as they were when first brought in contact with the case after admission. But one had to be practical and not suggest something which could not be carried out. That was why he had limited the endorsement of the medical opinion after four months to once a year for three years. Furthermore, clinical experience had shown the mental state at the end of that period to be commonly such that from the point of view of the necessity for continued detention, it would be foolish to enact anything which would demand frequent sanctions for the remainder of the patient's days in hospital. The importance of these first three years from this point of view was undoubted, and he wanted to emphasize this fact to ensure that every effort should be made to prevent cases slipping unnoticed into chronicity. After three years the present procedure with suitable alteration of the necessary document should suffice. There was, however, another point of view, i.e., the passing out of sight of chronic patients and a severance of all touch with the community, i.e., those without friends or neglected by them. It was partly for the purpose of preventing this that he had instituted his system of voluntary hospital visitors, but he thought something more could be done officially by establishing some procedure whereby the representatives of the local authority could, from time to time, give some special attention to these cases, perhaps find people to visit them and take an interest in their welfare.

$\mathrm{He}$, the speaker, was adverse to the multiplication of lunacy documents-the fewer the better was in the interest of all. The original medical statement, signed by one or two doctors, as the case might be, that the patient was in need of inpatient treatment, together with the statement of particulars, general report by the public assistance officer or in a private case by the medical attendant, should be the basic document of all actions taken. There should be endorsements to be deleted or retained, according to the type of case (voluntary detention, "nonvolitional," and involuntary detention cases, the last to be signed prior to admission by a member of the panel of " approved citizens," except in a case of grave emergency), and endorsements for sanctions or discharge after admission.

The document would need to be prepared in duplicate, except in voluntary cases, one being sent to the local authority as a notification, the other to accompany the patient to hospital. The Board of Control would determine what information they wanted, so he had no need to go into that. An alternative was a document ordering discharge not later than a fixed date (say four months after admission) after which it would become null and void if not endorsed otherwise. $\mathrm{He}$, the speaker, thought the former was more appropriate.

With regard to administrative areas for local government purposes, these were counties and county boroughs. The County Council took over all areas which were not within the confines of the county boroughs. All these areas could be split up as many times as was wished for public assistance work under public 
assistance sub-committees in London, guardian committees or sub-committees in the provinces. The county or county borough council could appoint suitable people in these localities, on the panel of "approved citizens" who were willing to serve. It was a matter for administration only. For supervision by social workers, the mental health areas could be further split up into sub-areas.

As regards the occurrence of mental disorder, the person to take the first step necessary to place the sufferer under treatment would be his nearest relative. That step was to send for the doctor. It was the doctor who notified the local authority. If public assistance was required, a public assistance officer would be soon on the scene, and act, if necessary, as the relative or friend of the patient. This answered one of Dr. Mortlock-Brown's queries. He, the speaker, thought she would find ample reply to her other queries when she came to study his address in print.

With regard to Dr. Carswell's speech, it would be lacking in courtesy on his, the speaker's part, not to refer to the fact that Dr. Carswell was a pioneer in early treatment without certification. (Applause.) In this country Dr. Toogood was not far behind him at one of London's Poor Law infirmaries. According to the Scottish Board of Control, $£_{1} 3$ was spent in the year 1927 in providing a special examination for patients who complained of wrongful detention. He, the speaker, did not know where the $f_{13}$ came from, because he had been told that the Lunacy Act for Scotland made no provision for this expenditure.

Dr. CARSwell: Don't ask.

Dr. LORD, continuing, said that another point concerned voluntary cases which became non-volitional. In England, as far as he, the speaker, knew, the Board of Control did not insist on either discharge or certification. If they did, some hospitals would have to close their doors to many patients.

With regard to the Scotch sheriffs, there was one with whom the speaker had had a long talk as to his duties. He found that that sheriff was a far better servant to the public in this respect than was commonly thought. In many cases he would send for the friends of the patients and for the doctor, and would go out of his way to make arrangements and offer suggestions as to what he considered the best to be done in the case, besides seeing that the committal documents conformed to the law. Hence in many cases certification was avoided.

As far as the Royal Mental Hospitals were concerned, one hospital at least had included in its new charter permission to retain certain cases without certification that was at the Morningside Nursing Homes, Edinburgh. That was not legal in England, but the London County Council and the City of London had had special powers allowing them to admit voluntary patients, the former at the Maudsley, the latter at Stone, Dartford.

Dr. Carswell had spoken of about $10 \%$ of the "ins and outs" of mental wards of Poor Law institutions who gravitated to mental hospitals, but in London the proportion was much higher-more like $50 \%$.

Referring again to Dr. Mortlock-Brown, the relatives in all mental cases certainly must have at least the chance of taking the responsibility for any action necessary ; they had the responsibility of initiating proceedings, and nothing in respect of what he was proposing should be done without consulting them.

As to notification, the great point the lady made was that the stigma of notification might be as great as that attaching to certification. With that he, the speaker, did not agree. Notification (confidential) to a public body by a practitioner that a patient needed in-patient treatment for mental disorder had no more stigma attaching to it than a notification that a person had smallpox. Coming back to Dr. Carswell's speech, the objection to the non-notification of the Glasgow cases he mentioned was that there should be some way of collecting statistics on menta diseases for the information of responsible government departments, so that the mental ill-health of the community could be assessed.

Dr. CARSwell: My Maudsley Lecture is full of that information, and reports are published every year.

Dr. LORD, continuing: If mental cases went in and out of general hospitals or clinics without such being required to furnish statistics to a local or a central authority, the extent of the work done and the state of the nation as regards mental disorder would never be known. Notification by individual names confidentially was not necessary unless there was detention, but there must be some statistical information gathered about all voluntary cases.

Dr. CARswell: I agree, and it is a scandal that there are so many private 
institutions in England which never publish a report, and we know nothing of what they are doing. I think every fact-not names-in this matter should be public property.

Dr. LORD : With regard to the remarks of Dr. Samuels, he did not think anybody present would sympathize with his words more than he, the speaker. That gentleman went out to work in a State more backward in the treatment of mental complaints than Europe in the Middle Ages, and out of the jungle there he had created a magnificent institution which compared favourably with the best in this country. It was an educational centre and carried out the latest forms of treatment. And, as Dr. Samuels pointed out, there had been a total abolition of judicial intervention-a lesson to this country. He was very glad of this opportunity of paying Dr. Samuels that tribute.

Dr. Petrie was a colleague of his own, and he, the speaker, did not mind telling him that what psychiatrists should do was to ask for what they wanted and needed, and what their patients needed, and fight for it. It was of no use to go to Parliament or to a body of lawyers and say, "We only ask for what we think you will give us." That had been done too long. He thought the Royal MedicoPsychological Association should now take up this matter in a bold way; it was the representative body of psychiatry and Parliament would take notice of its views, as, indeed, it had done in the past. Notice would still be taken of its demands if sufficient courage were shown. Few members had not some influence with a member of Parliament, and much could be done by propaganda. Success lay in proving what was needed and what was necessary for the patient, not in estimating what one was likely to get.

He thanked speakers very much for listening to him so patiently and for the helpful views they had put forward. His paper and discussion would appear in the Journal of Mental Science, and might be issued as a pamplet.

\section{Votes of Thanks for Hospitality.}

Dr. J. R. LORD said it fell to his lot, as the Acting General Secretary, to ask members to conclude the agenda by agreeing that a letter be sent to those who had afforded the Association such a fine hospitality as they had done at this annual meeting. He referred to the reception by the Mayor of Westminster, and to the very happy function which members enjoyed on the previous afternoon, by favour of the Visiting Committee of Springfield Mental Hospital.

Dr. Flour NOY (Switzerland) seconded, and it was carried.

Dr. Flournoy added: I would like, as a foreign guest, to say a few words. When the President of the Swiss Society, Dr. Forel, asked me to be a delegate to this meeting, I accepted without hesitation, because I was sure it would be a very great pleasure for me to be among you. If Switzerland has the advantage of being a country which has frontiers abutting on France, Germany, and Italy, the Swiss are equally anxious to keep in close contact with their friends further away, especially with those in Great Britain. We know how much we are indebted to you; we know how much the Royal Medico-Psychological Association has done, and will do, for the advancement of modern psychiatry. With regard to the birth, so to speak, of this branch of medicine, I should like to pay a tribute of gratitude to the memory of that great and wise citizen of York, William Tuke, who took the first steps towards mental hygiene and the care of the insane, and who did it without the help of any medical or scientific training, guided simply by his heart and by his love for mankind, which inspires your work also. It is an honour for me to have this opportunity of expressing the feelings of admiration which Swiss psychiatrists have for you. As to my own part, I must say I certainly shall not forget the wonderful mental hospitals which $I$ have seen in these last few days in London, and the extremely interesting communications which I have heard at the meeting. I speak also in the names of the representatives from Holland and from Germany, whose opinion is the same. I also express my heartiest thanks to the President and to the General Secretary for their invitation and for their cordial welcome. (Applause.)

The PRESIDENT: I am sure we are very grateful indeed for the kind remarks our friend has just made on his visit to our annual meeting. I envy him his good English. If I were to go as a delegate to his country, I am afraid I should not be- 
able to express my thoughts in the same lucid way. We are delighted to see him and the other foreign delegates, and I hope that on a future occasion we shall see them once more.

[The Annual Meeting then concluded.]

\section{APPENDIX I.}

REPORT OF THE MOTT MEMORIAL COMMITTEE TO THE COUNCIL.

The publication of the Mott Memorial Book under the title of Contributions to Psychiatry, Neurology and Sociology, dedicated to the late Sir Frederick Mott, K.B.E., etc., was reported to the May meeting of the Council, and now that the Committee appointed by the Council has almost concluded its labours it is fitting that an account of them should be put on record in the minutes of the Council.

The Memorial Book was published on May 16, 1929, and its reception by the Press was all that could be desired. The Committee trusts that members will not delay purchasing a copy, as it desires to close the account with the publishers as soon as possible.

The facts of the book's inception and publication are as follows: The death of Sir Frederick Mott on June 8, 1926, cast a shadow over the Opening Session of the Eighty-fifth Annual General Meeting of the Royal Medico-Psychological Association on July $\mathrm{I}_{3}$ of that year, and Dr. Frederick Lucien Golla spoke of a pretty custom abroad whereby all who so desired could contribute to a publication some fragment of appreciation or some useful piece of work inspired by the master they wished to honour or commemorate.

The new President, captivated by Dr. Golla's suggestion, took such steps as were necessary to carry it out.

The Council, in February, 1927 , readily acquiesced in the issue of a preliminary circular letter (in English and French) inviting those at home and abroad who had been Sir Frederick's pupils or colleagues, or in some way associated with him in his work, or who felt grateful for the help of his writings, to contribute something to a memorial book which would be a fitting recognition of all Sir Frederick had done for medical science, especially in regard to mental and nervous disorders and the physiology and pathology ot the nervous system. Contributions might take the form of original articles of neurological or psychiatrical interest, or commentaries or treatises on some aspect of his life's work or career.

A Mott Memorial Committee, composed of Sir Hubert Bond, K.B.E., Drs. F. L. Golla, Douglas McRae, Thomas Beaton and J. R. Lord, C.B.E. (Hon. Secretary) came into existence to see the matter through, and such was the response to this initial circular that a general appeal was issued in January, 1928, and a Mott Memorial Fund was opened with Dr. James Chambers as Treasurer.

Dr. J. R. Lord was appointed Editor and tife collection of materials from colleagues, friends, pupils and other admirers of Sir Frederick to be included in the Memorial volume commenced immediately. The order in which the articles appear was suggested by Lady Mott, who has taken a keen interest in the book from its inception. Articles written by a few of Sir Frederick's oldest and closest friends come first, after which the authors are in alphabetical order.

Subscribers were promised that many of the papers would be records of original work and important contributions to psychiatry, neurology and sociology, and that the book would be well illustrated, and the Committee feel that both these promises have been well kept.

Lady Mott has expressed her gratitude and satisfaction.

The Committee wish to thank most cordially the authors for their valuable contributions.

Through the generosity of Dr. Winkler no cost whatever fell on the book in respect of his fine illustrations. Other authors supplied the blocks for their illustrations as far as they were able.

The impress on the book of the long-established firm of medical publishers, Messrs. H. K. Lewis \& Co., was guarantee of its value, and the Committee beg to thank Mr. H. L. Jackson, the senior Director, for the great personal interest he took in every stage of its publication.

LXXV. 